\title{
Estimating the Heating Energy Consumption of the Residential Buildings in
} Hebron, Palestine

\author{
Shireen Bader Al Qadi \\ salqadi@lincoln.ac.uk \\ Prof. Behzad Sodagar \\ Dr. Amira Elnokaly \\ School of Architecture and the Built Environment \\ University of Lincoln, Lincoln, UK
}

Highlights

- Palestinian households spend 3.5\%-21.6\% of their monthly income on space heating during winter

- The average nominal heated area of the Palestinian houses is only $9.2 \%$ of the total dwelling area during a winter day

- A regression model for estimating the space heating is developed using 14 socioeconomic and physical parameters that have impact on the energy consumed for heating

Abstract

The domestic sector uses the majority of the energy consumed in Palestine. The Palestinian Central Bureau of statistics (PCBS) performs periodic statistics regarding the average energy consumption of the households, but there is no up to date breakdown of the energy consumption in the residential sector. The Palestinian energy sector main challenges are the high fuel prices, lack of sustainable consumption and energy insecurity. Developing energy policies and studying the potential of shifting towards more independent and sustainable energy sources needs a clear understanding of the current energy consumption. The main contribution of this paper is a regression model to estimate the energy consumed for heating in the housing sector in Hebron. The survey was used to collect quantitative and qualitative data. The total number of households in Hebron who responded to the survey was 322 households. The survey tackled physical characteristics of the dwellings, socioeconomic features of the households in addition to the pattern of heating the spaces, quantity and type of fuel used for heating. On average the households heated only $9.2 \%$ of the total area of their houses during the winter days. Based on the data collected from the survey, a regression model is developed to estimate energy consumption with an $\mathrm{R}^{2}$ adjusted 0.606 indicating $60.6 \%$ 
accuracy of the predicted energy consumed for heating. The regression model depends on 14 parameters which include the type of settlement, physical characteristics of the dwelling that are housing typology, level of thermal insulation of the walls, the main building materials and the housing age. In addition, to socioeconomic parameters which are the family monthly income and the occupancy period. Moreover, the type of the heating system used, the number of heated months and the nominal heated area were influential parameters in this model. The model can be used as a rule of thumb to estimate the energy consumed for heating in the Hebron housing sector by professionals, policy makers and building industry.

\section{Keywords}

Heating energy, housing typology, energy consumption; type of settlement, nominal heated area, regression model

\section{Introduction}

Palestinians procure most of their electricity and energy resources (excluding fuel wood) from Israel (Abu-Madi \& Abu Rayyan, 2013; Ibrik, 2009). The Palestinians have to pay the blue tax on the fuel amounting to $17 \%$ making energy less affordable to most Palestinians according to Paris Protocol (PASSIA, 2001). The annual energy consumption per inhabitant in Palestine is the lowest in the region (IEA, n.d). While energy consumption in $\mathrm{kWh} /$ capita in Israel was 3,955, in Jordan 1,426 in 2013, the annual energy consumption in Palestine was $790 \mathrm{kWh} /$ capita (IEA, 2014). The energy resources in Palestine is less affordable than anywhere else in the Middle East countries (Juaidi et al., 2016). Table 1 shows that the prices of different types of fuels in Palestine is almost double the price in the neighboring countries of Jordan and Lebanon. Fuel prices in Palestine is almost the same price as in Israel for the consumer despite the income gap between the citizens of the two regions. In 2011 the per capita income in the Israel is 150\% higher than the per capita income in the West Bank (Eckstein, 2011). Table 2 compares the residential electricity block tariffs in Lebanon, Jordan and Palestine. In these countries when tariffs are unable to cover the fuel source bill and operating costs, government subsidies cover the gap between expenditures and revenues. The electricity prices for the consumer in Lebanon is the lowest compared to Jordan and Palestine. While the prices for the blocks with the lower electricity consumption blocks in Jordan is lower than in Palestine, the prices in the higher consumption blocks is slightly higher in Jordan. The Israeli electricity tariff follows the voltage capacity with a peak/off peak and a seasonal tariff, hence, it cannot be compared with the previous countries (The Israel Electric Corporation LTD., 2012). 


\begin{tabular}{|c|c|c|c|c|}
\hline Fuel type & Lebanon & Jordan & Israel & Palestine \\
\hline Gasoline 95 & $0.60 \$ / \mathrm{L}$ & $1.41 \$ / \mathrm{L}$ & $1.89 \$ / \mathrm{L}$ & $1.97 \$ / \mathrm{L}$ \\
\hline Diesel & $0.86 \$ / \mathrm{L}$ & $0.80 \$ / \mathrm{L}$ & $2.27 \$ / \mathrm{L}$ & $1.83 \$ / \mathrm{L}$ \\
\hline LPG & $0.88 \$ / \mathrm{kg}$ & $0.82 \$ / \mathrm{kg}$ & $1.82 \$ / \mathrm{L}$ & $1.83 \$ / \mathrm{Lg}$ \\
\hline Kerosene & - & $0.73 \$ / \mathrm{L}$ & - & \\
\hline
\end{tabular}

Sources: (The Lebanese Ministry of Energy and Water,2018), (Jordan Ministry of Energy and Mineral Resources, 2018), (Israeli Ministry of National Infrastructures, 2018),(The Palestinian National Authority Ministry of Finance,2018). Prices for the consumer including VAT and currency conversion from JD and ILS to USD is based on $5^{\text {th }}$ February 2018 prices

Table 2: A Comparison Between the Electricity Prices for the consumer Between Lebanon, Jordan and Palestine

\begin{tabular}{|c|c|c|c|c|c|c|c|c|c|c|c|}
\hline $\begin{array}{l}\text { Blocks in } \\
k W h\end{array}$ & $1-100$ & $101-200$ & $201-300$ & $301-400$ & $401-500$ & $501-600$ & $600-700$ & $700-800$ & $800-900$ & $900-1000$ & $>1000$ \\
\hline Lebanon & 0.02 & & 0.04 & 0.05 & 0.08 & & & 0.13 & & & \\
\hline Jordan & 0.045 & & 0.1 & \multicolumn{2}{|c|}{0.12} & 0.2 & 0.24 & & 0.27 & & 0.36 \\
\hline Palestine & 0.15 & & .16 & 0.19 & \multicolumn{2}{|c|}{0.2} & \multicolumn{3}{|c|}{0.22} & & \\
\hline
\end{tabular}

Data from (Electricité du Liban, 2012), (National Electric Power Company, 2017) and (Palestinian Electricity Regulatory Council, 2017), Prices for the consumer including VAT and Currency conversion from JD and ILS to USD is based on 5th February 2018 prices

Due to the costly and insecure imported energy, in addition to the exigent and increasing demand, there is a potential for using different types of renewable energy sources (Al Qadi \& Alrjoub, 2011; Elnokaly \& Elseragy, 2007; Yaseen, 2009). The Palestinian Electricity Regulatory Department's recent statistics shows that there had been an increase in the energy production from renewable sources (mainly the solar photovoltaic cells) from 5,792kWh in 2015 to 6,253 kWh in 2016 (Palestinian Electricity Regulatory Council, 2017).

Rational Investment in renewable energy needs to be preceded by energy optimization. In Palestine, most of the energy consumed by the residential sector and should be among the targeted sectors in any energy policy that tends to shift to more sustainable energy technologies to increase energy security (Nejat et al., 2015; Ismail, Moghavvemi and Mahlia, 2013). Understanding the trend of the energy consumption is a first step towards optimizing the energy consumed for buildings. The Palestinian Central Bureau of Statistics (PCBS) energy surveys identify the amount of energy used by the household per month for certain months. Table 3 shows the average amount of electricity and fuel used by the Palestinian in the West Bank households for the different purposes during January 2015 based on the results of the last energy survey (PCBS, 2015). Obviously, no breakdown of the energy for specific uses like heating, cooling and appliances is defined. The latest breakdown of energy consumption in the housing sector was illustrated by Ouda (2010), who developed a detailed analysis of the annual energy consumption by the Palestinian households in the West Bank as demonstrated in Figure 1. The breakdown highlights that solar energy contribute significantly to the 
1 Domestic Hot Water (DHW) consumption (Ouda, 2010). It also shows that space heating comes in

2 the first category for using the hydrocarbon fuel.

3 Since 2010, many changes took place on the socio-economic situation. For example, the unemployment rate increased from $23.7 \%$ in 2010 to $26.9 \%$ in 2017 (PCBS, 2015). In addition, the family size in Palestine dropped from 5.8 in 2010 to 5.2 in 2015 (PCBS, 2011; PCBS, 2016a). Such socioeconomic changes have an impact on the energy consumed by the households (Al-Sumaiti, Salama and El-Moursi, 2017; Cai and Jiang, 2008; Swan and Ugursal, 2009).

Table 3: The Average Amount of Electricity and Fuel Used by the Palestinian Households in January 2015

\begin{tabular}{|c|l|l|l|l|l|}
\hline \multirow{2}{*}{} & \multicolumn{5}{|c|}{ Average household consumption of energy } \\
\cline { 2 - 6 } & $\begin{array}{l}\text { Electricity } \\
(\mathrm{KWh})\end{array}$ & LPG (Kg) & $\begin{array}{l}\text { Kerosene } \\
(\text { Litre })\end{array}$ & Gasoline (Liter) & Diesel (Litre) \\
\hline West Bank & 328 & 26 & 28 & 115 & 160 \\
\hline
\end{tabular}

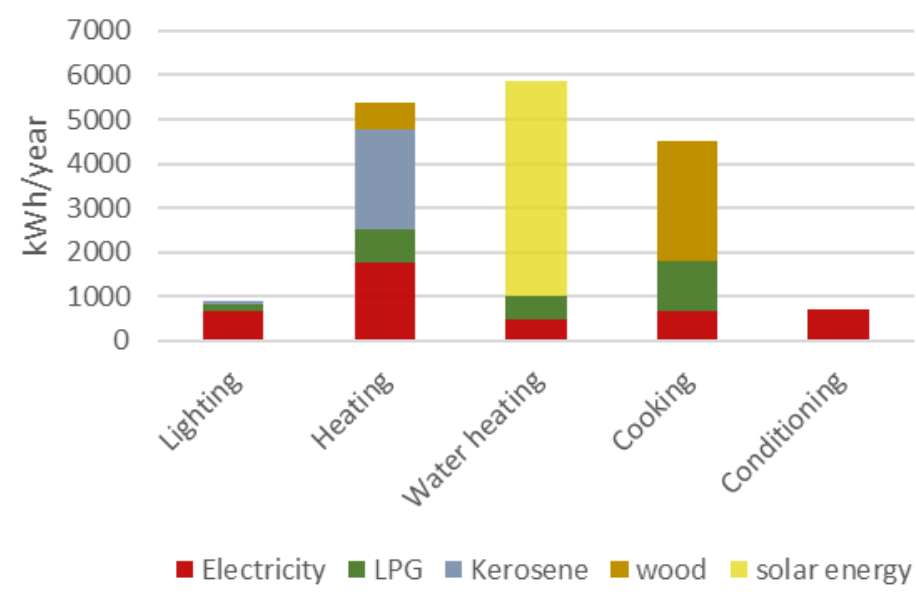

Figure 1: A Breakdown of the Annual Energy Used by the Palestinian Households in the West Bank (Based on Data from Ouda, 2010)

Models of the energy consumption in the housing stock is a key tool to implement the region's energy policies in an efficient and rational manner (Elnokaly \& Martin, 2014; Kavgic et al., 2010). However, estimating the energy consumption in developing countries where a combined energy sources used with primitive means like hand collected wood can be challenging (Wang and Jiang, 2017). Generally, no electricity sub-meters are installed in the Palestinian houses, and in some cases one electricity meter is installed for a number of houses to save the cost of connecting to electricity network formally. In addition, no gas network is available in the city. Furthermore, having more than one heating system is common in the Palestinian household to overcome electricity blackouts or running out of certain fuels. This can be due to poor infrastructure or in certain political situations like when fuel is not accessible due to Israeli closures on certain areas. In this context, the 
conventional ways of assessing energy consumption such as reading the electricity meters and gas bills are not suitable. (Aly et al.; 2017, Park et al., 2013; Sodagar \& Starkey, 2016; Upadhyay et al., 2017). An alternative approach is developed for assessing the energy consumed for the different uses in the Palestinian houses. In this paper, the heating energy consumption is estimated based on a heating system audit and calculating the amount of fuel used as will be explained in section 3 .

The goal of this paper is to create a model for predicting the heating energy consumed in Hebron residential buildings and to shed light on the main factors that influence the consumption.

Understanding the consumption of each of the uses like cooking and lighting is essential, however the main scope of this paper is the space heating energy due to the considerable amount of energy used for space heating in the Palestinian housing sector and because of its direct impact on the thermal comfort, health and wellbeing of the occupants. The research uses a mixed method approach (Creswell, 2003), combining both qualitative and quantitative data to develop a data driven model. The data was gathered through an empirical investigation using a multimode survey from 322 households. The survey defined the socio-economic characteristics of the household, the house physical characteristics, the pattern of space heating and an audit of the heating system's energy. These factors were examined statistically in SPSS (Guerra Santin, Itard and Visscher, 2009) using Ridge Regression Analysis (Tiwari, 2000) and 14 factors were found to be significant in determining the energy consumed for heating. The developed model can explain $60.6 \%$ of the energy used for heating in the Palestinian dwellings in Hebron. It can be used as a simplified tool for the professionals and policy makers to estimate the heating energy consumed based on physical parameters of the houses and socio-economic characteristics of the households. The significance of this paper stems from the methodology that propose an alternative to the energy audit and simulation methods. The proposed method can be used in contexts where a combination of energy resources are used with no proper metering system and with the absence of accurate data that is needed for simulation. Professionals, policy makers and the building industry can benefit from this method and results to estimate the heating energy consumption in Hebron and similar contexts. The paper is structured as follows, starting with a literature review defining the key performance indicators that impact the heating energy followed by research method, results, discussion and finally the conclusion.

\section{Key performance indicators to estimate the heating energy in the residential buildings}

In order to develop a model to predict the yearly heat consumption we need to take into account all the parameters that highly influence it (Catalina, Iordache and Caracaleanu, 2013). These indicators can be classified under three main categories which are environmental factors, building and system related factors, occupants' characteristics and behavior (Ali, Elnokaly \& Mills, 2017; Wei, Jones 
and de Wilde, 2014). Other parameters like energy policy and fuel prices are considered to have an equal influence in this context so were not included (Jones and de Wilde, 2014).

The climate in Hebron is generally a Mediterranean climate. However, the local climate is affected by the type of settlement. The fact that urban areas usually experience higher temperatures than the rural surroundings strictly connected with the urban heat island (UHI) phenomenon (Elnokaly \& Elseragy, 2007a; Kolokotroni and Giridharan, 2008; Salvati, Coch Roura and Cecere, 2017; Schwarzet al., 2012). Hebron Governorate contains the city of Hebron in addition to 17 municipalities and 32 village councils and two refugee camps that were established after 1948 (ARIJ, 2009; PCBS, 2010). The refugee camps were first established using tents by the United Nations for Relief and Works Agency (UNRWA) as temporary residences which were replaced by durable materials later on. The urban form and the density varies in these types of settlements. The literature mentions that the type of settlement can affect other parameters like the fuel choice. Households in the urban areas tend to use more clean fuels than rural households (Narasimha Rao and Reddy, 2007). In addition the type of settlement plays an important role on the family size and structure. The type of settlement is an important parameter in this study.

The second category includes the building and system related factor. Housing typology, building orientation, dwelling size, the number of heated rooms, building envelop U-value, the window to wall ratio, and building shape factor, height of the building, age of the building, , level of insulation were emphasized as a key factor of heating energy demand (Aksoezen et al., 2015; Andersson et al., 1985; Catalina, Iordache and Caracaleanu, 2013; Catalina, Virgone and Blanco, 2008; Elnokaly \& Elseragy, 2007b; Elseragy \& Elnokaly, 2007; Mutani, Gamba and Maio, 2016; Sardianou, 2008; Viggers et al., 2017; Wei, Jones and de Wilde, 2014). The contemporary housing in Hebron was classified in this paper based on a socio-physical criterion which is an extension of the traditional housing classification. The main housing typologies in this paper are the single housing, an apartment in a residential building, an apartment in a multistorey building for an extended family which is very common in the city of Hebron - and finally an apartment in mixed use housing. In addition, the heating systems features like the type and efficiency of heating system, type of temperature control, and type of heating fuel play a role in the amount of the generated heat and affects the total heating consumption (Wei, Jones and de, 2014). In the south of the West Bank (Hebron and Bethlehem) the main energy sources for heating are wood, LPG and electricity respectively (PCBS, 2015).

The third category which influences the energy used for heating is the households' characteristics like the occupants age, gender, social grade, household size and thermal sensation have an impact on the consumption (Ali, Elnokaly \& Mills, 2017; Bedir et al., 2013; Dong et al., 2015; Jones et al., 2015; Matsumoto, 2016; Santamouris, 2016; Wei, Jones and de, 2014). Furthermore, the economic 
situation is a main determinant of the heating consumption (Tiwari, 2000). Figure 2 illustrates the

2 main factors that contribute to the energy usage in the housing sector.

3 This research uses an empirical investigation through a survey method for data collection as will be

4 explained in section 3. Hence, the parameters that is included are the ones that are simple enough

5 for the respondents to answer. Technical parameters like U-value or efficiency of the heating

6 system were not included. In addition, parameters that needs spatial survey of the dwellings like the

7 openings to total area is not included too. In this paper 17 socioeconomic and physical parameters

8 are studied to determine their impact on the heating energy consumption as shown in table 4.

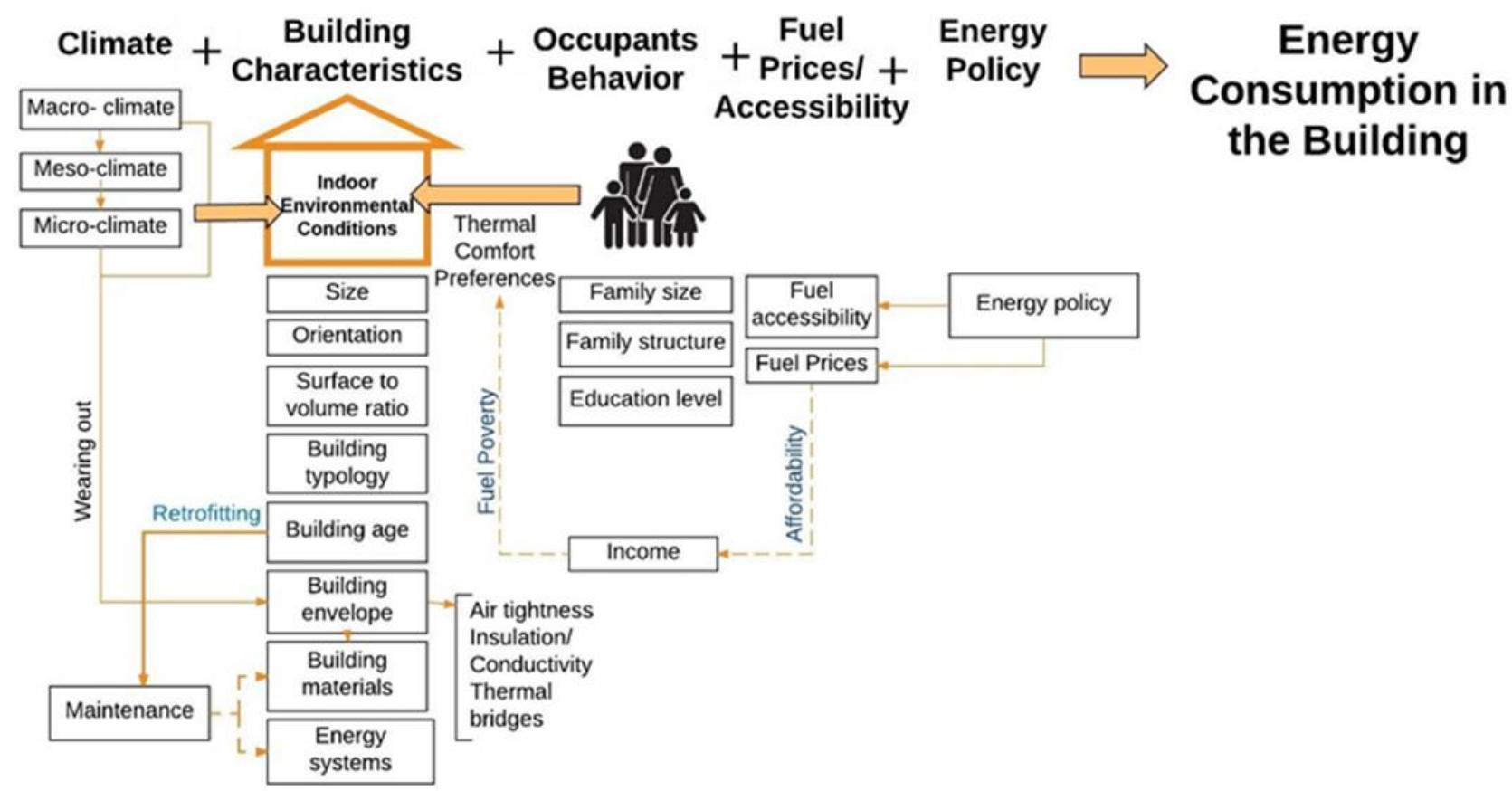

Figure 2: The Main Factors That Impact the Energy Consumption in the Residential Sector (Alqadi, Sodagar,Elnokaly, 2017)

\section{Table 4: Parameters Used in this Research for Modelling the Heating Energy Consumption}

\begin{tabular}{|l|l|l|l|l|l|}
\hline No. & \multicolumn{1}{|c|}{ Parameter } & No. & \multicolumn{1}{|c|}{ Parameter } & No. & \multicolumn{1}{|c|}{ Parameter } \\
\hline 1 & Type of settlement & 7 & Number of rooms & 13 & Using fire place \\
\hline 2 & Duration of occupancy & 8 & Main building materials & 14 & Using central heating \\
\hline 3 & Household size & 9 & Total monthly income & 15 & Using LPG heaters \\
\hline 4 & Occupancy rate & 10 & Heated area & 16 & Using Kerosene heaters \\
\hline 5 & Building typology & 11 & Level of thermal insulation of walls & 17 & Using electric heaters \\
\hline 6 & Building age & 12 & Number of months in which heating systems are used & & \\
\hline
\end{tabular}

13

\section{Research Method}

There are several ways to quantify the energy consumed in buildings. The bottom-up approach has the potential to model buildings in a detailed manner and to taking into account the interactions of the buildings, occupants and active systems (Lannon et al., 2016). It encompasses the energy 
physics approach, the statistical models and the hybrid approach (Foucquier et al., 2013; Kumar, Aggarwal and Sharma, 2013; Mocanu et al., 2016).

A growing interest is noticed in the statistical approach for calculating the energy consumption in buildings (Kneifel and Webb, 2016; Lü et al., 2015). The statistical method incorporates the macroeconomic and socioeconomic factors, easy to develop and use and is able to define a typical end-use energy consumption with no detailed data (Kavgic et al.,2010). However, the statistical method has some drawbacks as it relies on historical data to predict future consumption. In addition to the fact that it needs a large sample size making it time consuming (Baird and Bieber, 2016; Bozdogan, 2004). Moreover, there is the multicollinearity issue which is a condition in where the predictor variables are correlated with each other to some degree affecting the outcome (Baird and Bieber, 2016). These issues should be tackled carefully when developing the statistical models.

Due to the lack of detailed data on the actual thermal characteristics of the Palestinian residential buildings, the statistical approach was the most suitable method identified to be used in this research. It is beneficial in cases where it is difficult to collect detailed physical features like building geometry or thermal characteristics (Foucquier et al., 2013). Moreover, in the statistical models the user behavior needs not to be modelled which is a great advantage (Brøgger and Wittchen, 2017). In this research, the regression analysis is used (Montgomry, Peck and Vining, 2012). The next section of the paper discusses the regression models and how they are developed.

\subsection{Regression models}

Among the different types of the statistical methods, the methods of regression analysis are the most widely used statistical tools for discerning the relationships between variables (Draper $\&$ Smith, 2014). The regression methods are easy to implement, less computational power than other statistical approaches and gives satisfactory prediction ability (Fumo and Rafe Biswas, 2015). In Hebron case, due to unavailability of detailed data on the thermal characteristics of buildings and the absence of sub-meters in the houses, the regression modelling is adopted as a mean to predict the energy consumption.

The main idea behind the regression methods is finding a mathematical relationship (equation) between the dependent variable and explanatory variables (predictors) (Fumo \& Rafe Biswas, 2015). It can be applied using certain software like the Statistical Package for the Social Sciences (SPSS) and STASTICA (IBM, 2017) as well as Tibco Software (Tibco Software Inc., 2017).

In the multiple linear regression, all the available predictors are used together with the appropriate slope to quantify the effect of each predictor (James et al., 2013). The coefficient of determination $R^{2}$ assesses the quality of fit of the linear model. $\mathrm{R}$ square $\left(\mathrm{R}^{2}\right)$ is an important indicator when 
evaluating the regression model. It is the coefficient of determination that indicates the fitness of the model and can be understood as the amount of variation of the dependent variable explained by the regression equation (Anderson, 2003). The value of $\mathrm{R}^{2}$ varies between 0 and 1 and the preferred model would be with an $\mathrm{R}^{2}$ value close to 1 (Yan \& Sue, 2009). If for example, the value of $\mathrm{R}^{2}=0.85$ this points out that $85 \%$ of the total variability of the dependent variable is defined by the predictor variables in the model (Fumo \& Rafe Biswas, 2015). In this research Ridge regression model was used. In regression analysis, Ridge estimators are often used to alleviate the problem of multicollinearity which happens when the factors have a correlation with each other that can affect the final results of the model (Wan, 2002).

Linear regression has been used in several studies to define the factors that influence and predict the energy consumption in the buildings (Amiri et al., 2015; Braun, 2014; Pulido-Arcas et al., 2016). For example, a multivariate regression analysis was used to explore the overall effect of socioeconomic and behavioral variables on residential energy consumption of conditioned space in China, based on data obtained from surveys (Chen, Wang \& Steemers, 2013). Similarly, it has been used to understand the effects of environment indicators and household features on residential energy consumption (Tso \& Guan, 2014).

Creating a regression model needs usually a large set of data (Bozdogan, 2004). Concomitantly, the mixed method was used in this research in order to combine the strengths and perspectives of both the qualitative and quantitative methods. It is also believed that this approach emphasizes the real human experience by considering both the qualitative and quantitative aspects in the research (Johnson \& Onquegbuzie, 2004). The survey method was used in this paper to collect the data.

\subsection{Designing the questionnaire}

For collecting a large set of data to estimate the energy used for heating and cooling in buildings various studies have adopted the survey method (Jridi \& Nouri, 2015; Hu et al., 2017; Santamouris et al., 2013; Zheng et al., 2014). The survey main strategy is to collect the same information about all the cases in a sample (Aldridge and Levine, 2001). The flexibility in the survey method allows many variables to be included producing a large amount of data, hence, allowing hypothesized relationships to be tested (Baker, 1999). Meanwhile, it is possible that this data lacks the depth on the topic (Kelley, 2003).

The questions of the survey were a combination of multiple choices using Likert scale in addition to using matrix questions (Fowler, 2009). The questionnaire was divided into four main parts. The first part tackled the household characteristics, such as the number of occupants, income and age range. The second part focused on the housing properties, such as age, building materials, location, 
typology and area. These parts included the main physical and socio-economic factors that potentially have an impact on the energy consumption for heating and cooling. Figure 2 is an example of the questions that focus on the socio-economic situation of the households. The third section concentrated on the heating and cooling patterns in the spaces, type of fuel and system used and frequency of heating (see Figure 3). The fourth part assesses the thermal comfort however it is not discussed in this paper.

\begin{tabular}{|c|c|c|c|c|c|c|c|c|c|c|c|c|}
\hline & 0 & 1 & 2 & 3 & 4 & 5 & 6 & 7 & 8 & 9 & 10 & $\begin{array}{l}\text { more } \\
\text { than } 10\end{array}$ \\
\hline $0-5$ years & 0 & 0 & 0 & 0 & 0 & O & 0 & 0 & $\mathrm{O}$ & 0 & O & 0 \\
\hline 6-12 years & O & O & $\mathrm{O}$ & 0 & O & O & O & O & $\mathrm{O}$ & $\mathrm{O}$ & O & 0 \\
\hline $13-22$ years & 0 & 0 & $\mathrm{O}$ & 0 & O & 0 & 0 & 0 & $\mathrm{O}$ & O & 0 & 0 \\
\hline $23-35$ years & $\mathrm{O}$ & $\mathrm{O}$ & $\mathrm{O}$ & O & O & O & 0 & O & 0 & O & O & 0 \\
\hline $36-60$ years & 0 & $\mathrm{O}$ & O & 0 & O & O & O & 0 & $\mathrm{O}$ & O & $\mathrm{O}$ & 0 \\
\hline more than 60 years & O & $\mathrm{O}$ & O & $\mathrm{O}$ & O & O & O & $\mathrm{O}$ & $\mathrm{O}$ & $\mathrm{O}$ & O & O \\
\hline
\end{tabular}

\section{Figure 3: A Sample of the Survey Questions on the Socio-Economic Characteristics of the Households (Authors'} Own $)$ - (1000 ILS=281.2\$ in 01/08/2017)

The questions were designed to fit the purpose within the specific Palestinian context. The respondents could select more than one choice of the heating systems if applicable. The households were asked about the type of electric heating system used and duration of using. Fuel delivery takes place in fundamentally primitive ways. For example, people who rely on liquefied gas petroleum (LPG) for heating generally use bottles of $12 \mathrm{~kg}$ capacity and others use kerosene tanks. The households were asked about the number of LPG bottles consumed per month. Estimating the amount of kerosene used in litres can be hard for the households, hence they were asked about the frequency of filling the tanks during the heating season in order to calculate the fuel consumption taking into account average capacity of the kerosene tanks of the common used heating systems. The respondents defined also the total amount of wood they used for heating in tonnes.

\subsection{Sampling method}

A multi-mode survey depends on more than one way of collecting data to increase the response rate and decrease the cost (Biffignandi \& Bethlehem, 2012). In this research, the web based surveys and questionnaires were used. Web based survey have several advantages including the decrease in cost and ease of analysis, but also have drawbacks including the potential for selection bias (McPeake, Bateson and O'Neill, 2014). In this research, the electronic survey tool Smartsurvey was used in addition to the hard copy self-complete questionnaires to increase the credibility of the survey 
results in December 2016. Smartsurvey was found to be a suitable tool since it enables the survey to be created in different languages - Arabic in this case - and to have clear, undisturbed Excel spreadsheet results afterwards. Snowball sampling was used to address the energy consumption in the housing sector (Sesan, 2012; Wall \& Crosbie, 2009).

The sample size of the Energy Survey that was held in 2015 by the PCBS were 87,656 households among them 740 households were from Hebron district (PCBS, 2015a). No formal statistics are available regarding the current total number of the households in Hebron as the consensus results of 2017 was not published yet. Some statisticians dispute the logic that sample size is necessarily dependent on population size (Alreck and Settle, 2004). Defining sample size can be derived depending on the researcher acceptable error (Roscoe 1975). A level of error of $10 \%$ is considered acceptable (Roscoe 1975). Aiming for a margin of error (based on 95\% confidence interval) at the most of $+/-6$ percentage points for each possible response a sample size of 266 would be needed (Creative Research systems, 2012; Assheton,2017).

The total number of responding households from both methods in Hebron was 322, which exceeds the required sample. The number of respondents from Hebron using the internet survey method were 259. The main criticism of the internet-based sampling is that they cannot be generalized as they are unrepresentative (Bethlehem and Biffignandi, 2012). However, according to the formal statistics $48.3 \%$ of the Palestinian households has a connection to the internet (PCBS, 2014). On the other hand, there are other means of connecting to the internet like a connection from a workplace, or other informal means. In order to increase the credibility of the survey results and to eliminate the internet sampling, 100 questionnaires (hard copies) of the survey were distributed during a visit to Hebron in December 2016. These were self-complete questionnaires, with the aim to address the people who might have no internet access or are unfamiliar with internet use to participate in the survey. The number of responses using this method was 63 (returned percentage of $63 \%$ ).

\subsection{Heating energy calculations}

The respondents first had to choose the type of energy used for heating. The main types of fuel used for heating in Palestine are wood, LPG, kerosene and diesel, in addition to electricity (PCBS, 2015a). Each of these fuels' consumption was calculated using a certain formula depending on the frequency of consumption of the heating system. Each heating system of wood, LPG, kerosene and diesel was assigned a coefficient in order to calculate the energy in $\mathrm{kWh}$ as demonstrated in Table 5. 

2009)

\begin{tabular}{|c|c|c|}
\hline Energy Type & $\begin{array}{c}\text { Reporting } \\
\text { Units }\end{array}$ & Conversion Factor \\
\hline Wood Logs & Tonne & 2,778 \\
\hline LPG & Kilogram & 13.7 \\
\hline Diesel & $\mathrm{m}^{3}$ & 10800 \\
\hline Kerosene & Litre & 10.3 \\
\hline
\end{tabular}

3

4 For wood, households usually buy or collect a certain amount of wood in tonnes. For the LPG

5 heating systems bottles of $12 \mathrm{~kg}$ are used. The capacity of the kerosene heating system tanks is six

6 litres on average and filled regularly, while diesel is stored in tanks and filled periodically.

7 Regarding the diesel and the kerosene tanks it has been assumed that the tanks are refilled when

$810 \%$ of the tank is left. Hence the following Equation 1,2,3 and 4 present the formulas that were

9 developed to estimate the annual heating consumption (AHC) from wood AHC (wood), LPG AHC (LPG), Diesel AHC (Diesel) and Kerosene AHC (kerosene) respectively:

$$
\left.\mathrm{AHC}(\operatorname{wood})=\mathrm{T}^{*} 2778(\mathrm{kWh}) / \text { year }\right)(\text { Eq. 1) }
$$

T: number of tonnes of wood used annually for heating

2778: coefficient to transfer the heat from tonnes of wood to $\mathrm{kWh}$ (Table 4)

$$
\left.\mathrm{AHC}(\mathrm{LPG})=\mathrm{B}^{*} \mathrm{~N} * 12 * 13.7(\mathrm{kWh}) / \text { year }\right)(\text { Eq. } 2)
$$

B: Number of bottles consumed per month during heating seasons

N: Number of Heating months

12: Amount of $L P G$ in a bottle $(\mathrm{kg})$

13.7: coefficient to transfer the heat from $\mathrm{kg}$ of LPG to $\mathrm{kWh}$ (Table 4)

$\mathrm{AHC}($ Diesel $)=\mathrm{V} * \mathrm{~T} * 10800 * 0.9(\mathrm{kWh}) /$ year $)($ Eq. 3)

V: volume of the Diesel tank in $\mathrm{m}^{3}$

T: Number of times of filling the tank per heating season

10800: Coefficient to transfer the heat from $\mathrm{m}^{3}$ of Diesel to $\mathrm{kWh}$ (Table 4)

0.9: assuming that the tank will be refilled when it reaches $10 \%$ of its capacity 
AHC $($ kerosene $)=6 * \mathrm{~N} * \mathrm{D} * 10.3 * 0.9(\mathrm{kWh}) /$ year $)($ Eq. 4)

6: The average tank size $(L)$

$N$ : Number of Heating weeks

D: Number of times of filling the tank per week

10.3: coefficient to transfer the heat from L of Kerosene to $\mathrm{kWh}$ (Table 4)

0.9: assuming that the tank will be refilled when it reaches $10 \%$ of its capacity

Equation 1. Formulas were developed to estimate the annual amount of heating energy consumed from wood AHC (wood), LPG AHC (LPG), Diesel AHC (Diesel) and Kerosene AHC (kerosene)

To assess the energy used in the heating using electrical systems, the most commonly used heating electricity systems in the Palestinian market were explored and the average amount of wattage of each system was taken from the producer catalogues as illustrated in Table 6.

Table 6: The Common Heating Systems Used in the Palestinian Market (Universal, 2015; Europa, 2015)

\begin{tabular}{|l|c|c|c|c|c|c|}
\hline Number & $\mathbf{1}$ & $\mathbf{2}$ & $\mathbf{3}$ & $\mathbf{4}$ & $\mathbf{5}$ \\
\hline $\begin{array}{l}\text { Heating } \\
\text { system }\end{array}$ & & & & & & \\
\hline
\end{tabular}

The amount of electric energy consumed (AEC) Electricity for heating per year was calculated using the following formula:

$\operatorname{AEC}\left(\right.$ Electricity) $=W^{*} H^{*} 30 / 1000(k W h) /$ year) (Eq. 5)

During site visits of 30 houses in Hebron the temperature inside the houses in winter was measured. The average temperature was found to be $12.6 \mathrm{C}^{\circ}$ in the sitting rooms in the 30 houses. It was also 
wattage to get the maximum amount of heat. Hence, the equation of the electric heaters assumes that systems 2 and 4 in Table 6 operate on the maximum wattage.

In addition to the previous systems, people also use air conditioning system, not only for cooling during summer but also for heating during winter. In this case, the respondents had to choose the wattage and the number of the air conditioning systems, in addition to the duration of use during the heating seasons. The wattages for heating for different air conditioning systems obtained from their catalogues are given in Table 7.

Table 7: The Average Heating Wattage of the Air Conditioners in Common Heating Systems Used in the Palestinian Market

\begin{tabular}{|c|c|c|c|}
\hline Product & Model & Wattage for heating & Source \\
\hline Media Air conditioning system & Platinum-18GIQ & 0.96 & (Media, 2015) \\
\hline Media Air conditioning system & Platinum-23GFI & 1.56 & $($ Media, 2015) \\
\hline Media Air conditioning system & Platinum-32GIQ & 1.87 & (Media, 2015) \\
\hline
\end{tabular}

The annual energy consumption by the air conditioner systems for heating was calculated using the following formula:

AEC (electricity) $=\mathrm{W}^{*} \mathrm{H}^{*} \mathrm{~N} / 1000(\mathrm{kWh}) /$ year) (Eq. 6)

W: Wattage (optained from the producer catalogue for each system shown in Table 6)

H: Hours in which the system used per day

$N$ : Number of heating days during the heating season

Equation 3. Formula to calculate the annual energy consumed by the air conditioner systems for heating

The greatest limitation of this model is not being able to obtain detailed technical data from the correspondents as the survey questions should be simple to increase the response rate. The second limitation is the multicollinearity which was overcame using ridge regression model as explained in Figure 4 that summarizes the method used in this paper.

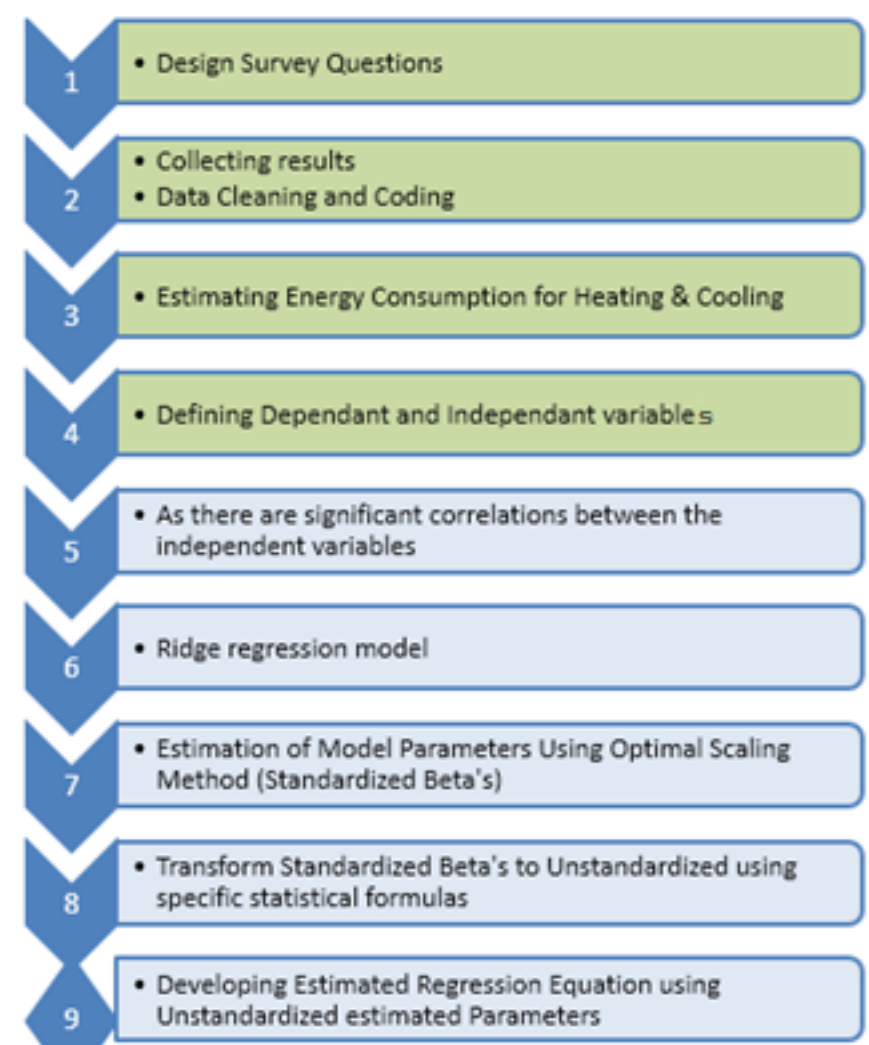

Figure 4: A Summary of the Methodology 


\section{Results}

\subsection{Type of settlement}

The percentage of respondents living in the different types of settlements compared to the Palestinian Central Bureau of Statistics data of 2016 is illustrated in Table 8. The variation in the results could be due to the difference between the formal and the informal classification of the settlements. While the government recently considered 17 settlements in Hebron Governorate as cities, the residents still tend to consider the city of Hebron as the main city and the rest of the settlements as towns or villages, which was reflected in the variation in the city and villages percentages between the formal statistics and the survey results in this research.

Table 8: The Percentage of the Respondents Who Live in the Different Types of Settlements Compared to the Palestinian Central Bureau of Statics of Population (PCBS,2016 $)$

\begin{tabular}{|c|c|c|c|}
\hline Type of settlement & City & Rural areas & Refugee camps \\
\hline Survey,2017 & $64.3 \%$ & $33.9 \%$ & $1.9 \%$ \\
\hline PCBS,2016 & $85.3 \%$ & $12.0 \%$ & $2.6 \%$ \\
\hline
\end{tabular}

\subsection{Households' socioeconomic characteristics and heating costs}

The average households' size in the survey is 5.8. The average monthly income of the households in this survey is 4473.6 ILS (\$1263.5). Around 37.6\% of the households are under the poverty line, which is 2293 ILS (\$665.6) per month as a reference for households consisted of two adults and three children according to the PCBS in 2011 (PCBS, 2011). Figure 5 demonstrates the percentage of the total monthly income that the households pay. The results show that there is a reverse correlation between the households' income and the percentage spent on heating. While the households with income 1400 ILS ((\$400.3) pay one fifth of their monthly income, households with monthly income that exceeds 12000ILS $(\$ 3,374.4)$ pay less than $5 \%$ of their income for heating in both the city and the villages.

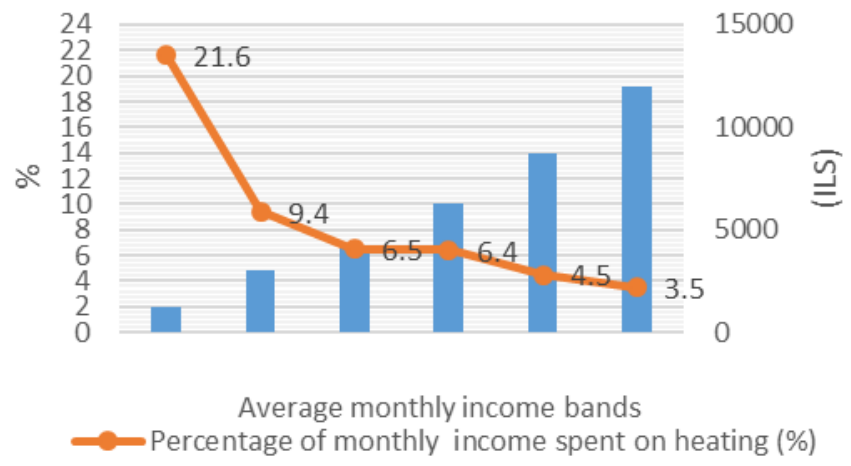

Figure 5: The Percentage of the Heating Expenses from the Households' Monthly Income 
2 The survey reveals that the dominant housing typology differs according to the type of settlement.

3 Table 9 shows the percentages of the housing typologies in the city, the villages and the refugee camps in Hebron and compares them to the PCBS (PCBS, 2015 a). The single housing is the dominant typology followed by the apartments in an extended family residential building in the city and the villages. The latter is a common typology in Hebron, not only as a result of the land scarcity and economic limitations which force the sons to build over the roof of their parents' house, but it is also a reflection on the importance of the extended family in the local culture. Almost one fifth of the households in the city and the villages live in apartments in residential buildings. However, the situation in the refugee camps is different. The land is rented by the United Nations for Refugees and Works Agency (UNRWA) from the owners of the land and all the houses within the refugee camps' boundaries are registered in the UNRWA (Barahmi, 2016). The refugee households expand in the very limited area available or add new units over the existing structures.

Table 9: The Housing Typologies Percentage in the City, Villages and Refugee Camps in Hebron in the survey vs. PCBS

\begin{tabular}{|l|c|c|c|c|c|}
\hline $\begin{array}{c}\text { Type of } \\
\text { settlement }\end{array}$ & $\begin{array}{c}\text { Single } \\
\text { housing\% }\end{array}$ & $\begin{array}{c}\text { Apartment in } \\
\text { a residential } \\
\text { building\% }\end{array}$ & $\begin{array}{c}\text { Apartment in an } \\
\text { extended family } \\
\text { residential building\% }\end{array}$ & $\begin{array}{c}\text { Apartment in a mixed- } \\
\text { use building\% }\end{array}$ & Other \\
\hline City & 50.3 & 19.7 & 28.4 & 1.6 & - \\
\hline villages & 48.8 & 20.8 & 28 & $00.4 \%$ & - \\
\hline Refugee camps & 16.7 & 33.3 & 50 & $36.1 \%$ & $0.4 \%$ \\
\hline Hebron Governorate in (PCBS) & $63.5 \%$, & \multicolumn{3}{|c|}{} \\
\hline
\end{tabular}

\subsection{Housing Area}

The area of the housing units was calculated by multiplying the number of rooms by $12 \mathrm{~m}^{2}$ and the number of bathrooms by $5 \mathrm{~m}^{2}$ which is the average size of the room and bathroom in the Palestinian housing market (Al Qadi, Sodagar, and Elnokaly, 2017). The average calculated area of the housing units of the respondents is $125.9 \mathrm{~m}^{2}$ similar to the official statistics in 2015 indicating that the average area of the housing units in Palestine is $126.2 \mathrm{~m}^{2}$ (PCBS, 2015). The survey results show that the single housing has the largest average area and that the apartments in residential buildings has the smallest area as depicted in Figure 6.

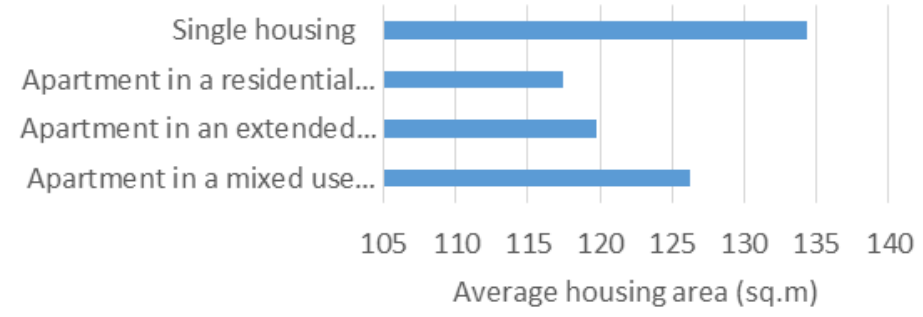

Figure 6: The Average Area in the Different Housing Typologies 
Like many parts of the Middle East, the building sector in Hebron suffers from scarcity of the thermal insulation (Elnokaly \& Elseragy, 2007b; Lazzeronia et al., 2017). Figure 7 shows the level of insulation of the different types of housing. Generally using floor and floor thermal insulation is not a common practice. The respondents were asked about the walls thermal insulation. The survey shows that partial insulation in the external walls is common.

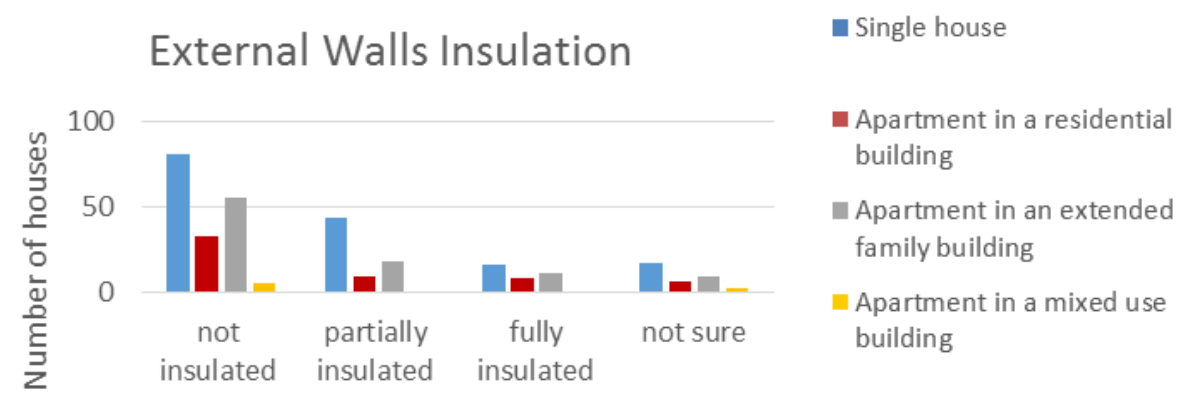

Figure 7: Thermal Insulation Level in the Different Housing Typologies

\subsection{Heating trends and heating systems used}

The survey revealed that $99.6 \%$ of the households heated their houses during winter. In 2015 , the PCBS indicated that $6 \%$ of the households in the West Bank did not heat their houses (PCBS, $2015_{a}$ ). The variation between this survey and the official statistics is mainly due to the geographical differences. The official statistics studied the West Bank including the Jordan Valley region. The average temperature in Jordan Valley was $24.9^{\circ} \mathrm{C}$ between 2009 and 2016 and is generally warm during winter so many households do not need to heat their houses according to the responses of the survey (PCBS, 2016 $)$. On the other hand, the average temperature during the same period in Hebron was $16.9^{\circ} \mathrm{C}$ with cold winters forcing most of the households to use a source of heating (PCBS, 2016 $)$.

The households essentially rely on more than one type of heating system using different fuels to compensate for any fuel deficiencies or electricity blackouts. The survey revealed that there is a variation between the heating systems used in the different types of settlements as demonstrated in Figure 8. The dominant heating system is the electric heaters in all types of settlements. This could be due to the accessibility of electricity, as $99.9 \%$ of the Palestinian houses are connected to the electricity network (PCBS, 2015a). The highest percentage of households relying on electricity heaters was in the refugee camps. The reason for this high percentage could be due to the government's occasional subsidization of the electricity bills to support the refugees.

The second type of heating system in all of the settlements was the LPG heaters. Despite the fact that LPG heaters are unsafe, they are popular since unlike most of the electrical systems, 
1 households prepay for the LPG bottles and thus control their heating expenses. The percentage of

2 households using this system in the city was higher than in the villages or the refugee camps. The main reason behind this pattern of consumption is that the number of local distributors and frequency of supply in the city is better than in the villages or the refugee camps making it more accessible to households in the city. Around $37.0 \%$ and $22.0 \%$ of the households in the city and the villages respectively used the air conditioning system for heating. People tend to use them since they are safer and distribute the heat better than the conventional electric heaters.

The type of settlement with the highest percentage of wood burning fireplaces was the villages, followed by the city and the refugee camps as the wood there is more accessible. Central heating systems were popular for heating the houses in Palestine during late eighties and the early nineties. The use of central heating was popular when the fuel prices were reasonable; however, the use of this system declined because of the increase in oil prices. Many of the houses that installed central heating systems do not use them anymore because of the high cost of the fuel. Figure 8 shows that central heating is only used in the city, contributing to $8.7 \%$. None of the households in the villages or the refugee camps uses central heating.

Furthermore, the survey showed that kerosene heaters are not popular in Hebron, with only $2.9 \%$ of households in the city using them. This is due to the increase in kerosene prices and other heating systems being safer to use. Finally, only $1.4 \%$ of the households in the city said that they use solar thermal heating systems in their homes.

The (PCBS) use a different way of classification when defining the main heating systems used by households. In 2015 households energy survey $72 \%$ of the households used a heater (electrical, LPG and kerosene), $31 \%$ used wood burn heaters and $3.6 \%$ used the central heating in the south of the West Bank. This classification does not reflect the fact that many of the households use a mixture of several heating systems (PCBS, 2015b).

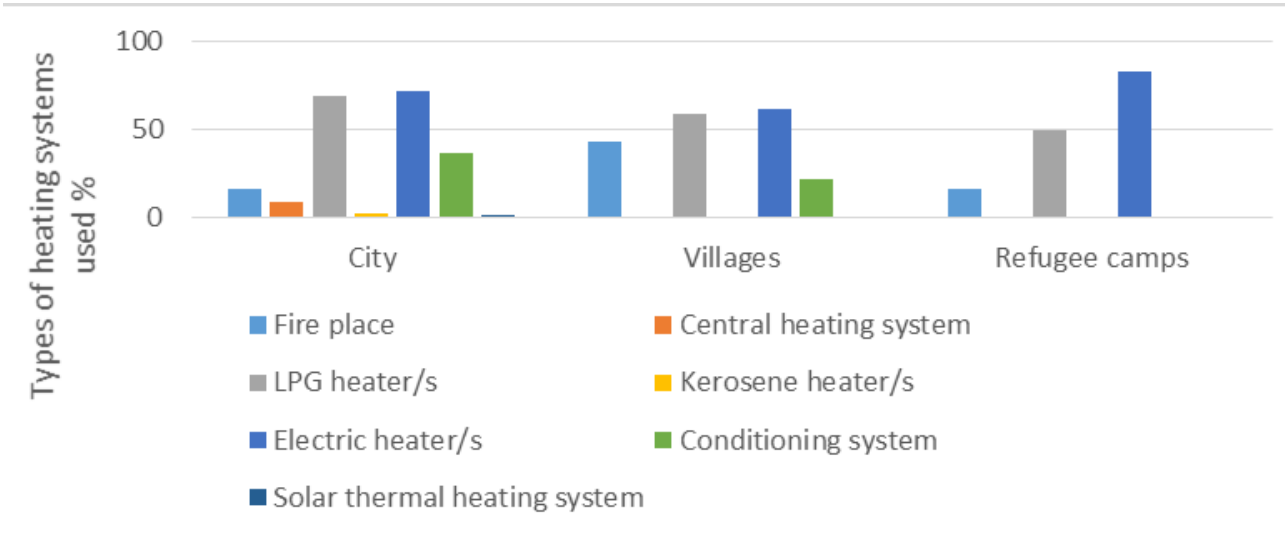




\section{Discussion}

\subsection{Comparison with previous studies}

The survey showed that the Palestinian households' average energy consumption for heating per household in Hebron Governorate is $2785 \mathrm{kWh} /$ year. Ouda (2010) estimated the average annual energy used for heating in the West Bank was $5286 \mathrm{kWh}$. The variation between this survey and the previous study could be a combination of factors including location, climatic differences, socioeconomic discrepancies as well as the time lag between the two surveys. The study in 2010 included all the cities in the West Bank but this survey studies the heating consumption in the households in Hebron. The variation in the climatic conditions of these cities, social and economic characteristics of the households in the different regions can have an impact on the results.

Furthermore, the time span between the two surveys is almost ten years in which economic and social changes has taken place. For example, the fuel prices have increased dramatically in Palestine during the last 10 years. Figure 7 demonstrates the crude oil prices between 1999 and 2015 (Historical Crude Oil Prices, n.d) versus the Palestinian households' overall consumption of the different kinds of energy sources for the years 1999, 2003, 2005, 2010 and 2015 (PCBS, 2000; PCBS, 2004; PCBS, 2006; PCBS, 2011; PCBS, 2015a). There is a negative relation between the fossil fuel prices and the households' consumption as depicted in Figure 9. It also indicates a positive relation between using wood and the fossil fuel prices. The increase in the price of crude oil between 1997 and 2007 was around 244.4\%. The price decreased in 2016 but it was still higher than 1997's price by $84.5 \%$. The local political situation is another reason behind the consumption trend in Figure 9. The Palestinians faced a great economic deterioration during the Second Palestinian Uprising (Intifada) that took place in September 2000, increasing the unemployment rate from $14.6 \%$ in 2000 to $33.5 \%$ in 2002 (PCBS, 2016 b). The Second Uprising was followed by a strict closure on the cities and villages by the Israelis, decreasing the accessibility and the affordability of the fuel in addition to most of the basic products (Pressman, 2006). 


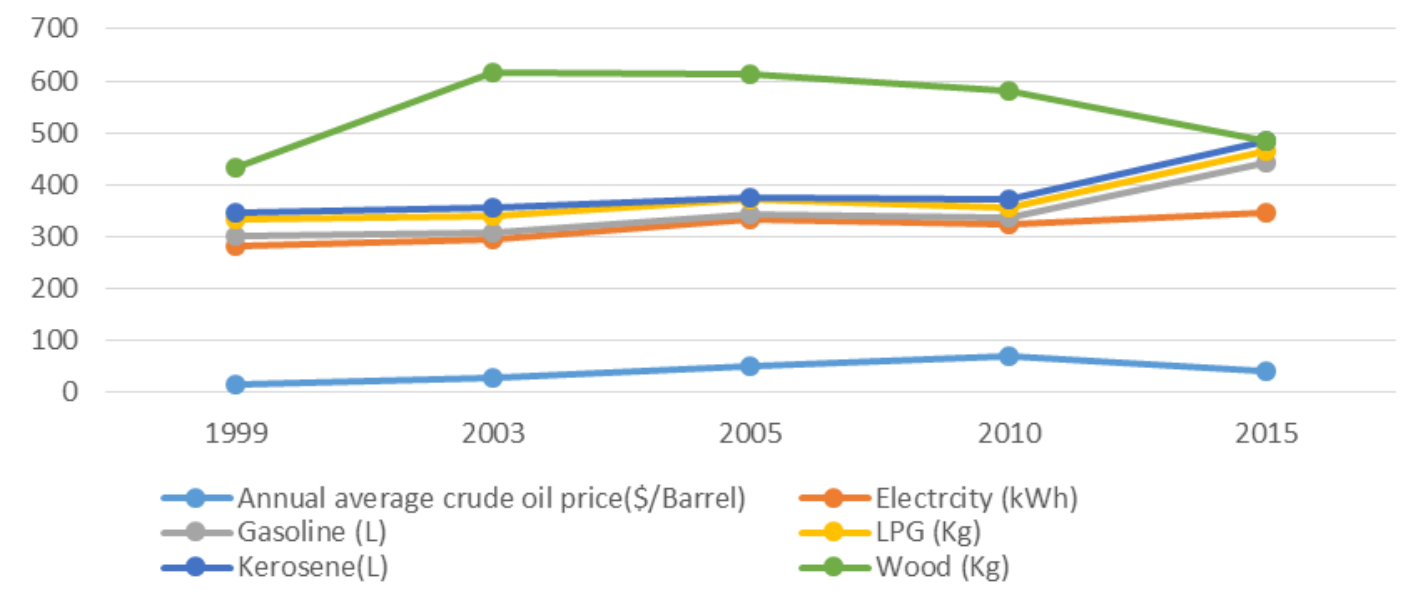

Figure 9: Annual Average Crude Oil Prices (In \$/Barrel) vs. the Average Monthly Consumption of Different Types of Fuels by the Palestinian Households (InvestmentMine, 2017); (PCBS, 2000); (PCBS,2004); (PCBS,2006); (PCBS,2011); (PCBS,2015)

\subsection{Heating energy, type of settlement, housing typology}

A variation was found between the heating energy consumed in different settlements. The average heating energy calculated in this survey was $3555.9 \mathrm{kWh}, 1400.4 \mathrm{kWh}$ and $1335.1 \mathrm{kWh}$ in the city, villages and refugee camps respectively. The single housing has the highest consumption of heating energy in all the settlements due to larger envelop area as compared to other housing typologies. The consumption in the apartments in the residential buildings in the city is less than the apartments in the extended family multistory building. This can be due to that extended households share the energy resources in many cases. Having one electricity meter for the extended family is an example of that. This procedure leads to an increase in the consumption by the individual households. On the contrary, the consumption of the households who live in an apartment in an extended family building in the villages is less than the households living in residential buildings. This is probably because the households in the villages tend to spend more time together in one apartment during the day which decreases the amount of energy consumed for heating. Finally, the consumption in the households in the mixed-use buildings in the city and refugee camps is the lower than the other typologies within the same settlement. Non- residential spaces are not properly heated in mixed use buildings and hence increased heat loss from dwellings to these spaces and due to lack of insulation, households tend to not to consume energy that will be wasted by heat loss.

\subsection{Heating energy, income and family size}

Figure 11 illustrates the annual energy consumed for heating in the different housing typologies in different settlements versus the average households' monthly income for each of the housing typologies and the size of the household. In this study, a relationship can be seen between the monthly income of the households and the energy consumed for heating in the refugee camps as illustrated in figure 10. However, no clear relationship was found between the households' income 
and the energy consumed for heating in the cities and villages. Nevertheless, the variation of the energy consumption can be a reflection of different comfort preferences of the households in the different settlements. A significant positive relationship between the family size and energy use was depicted by Badir (2013). In this survey, a relationship was found between the households' size in the city and the heating energy consumption; however, this is not applicable in the villages nor in the refugee camps.
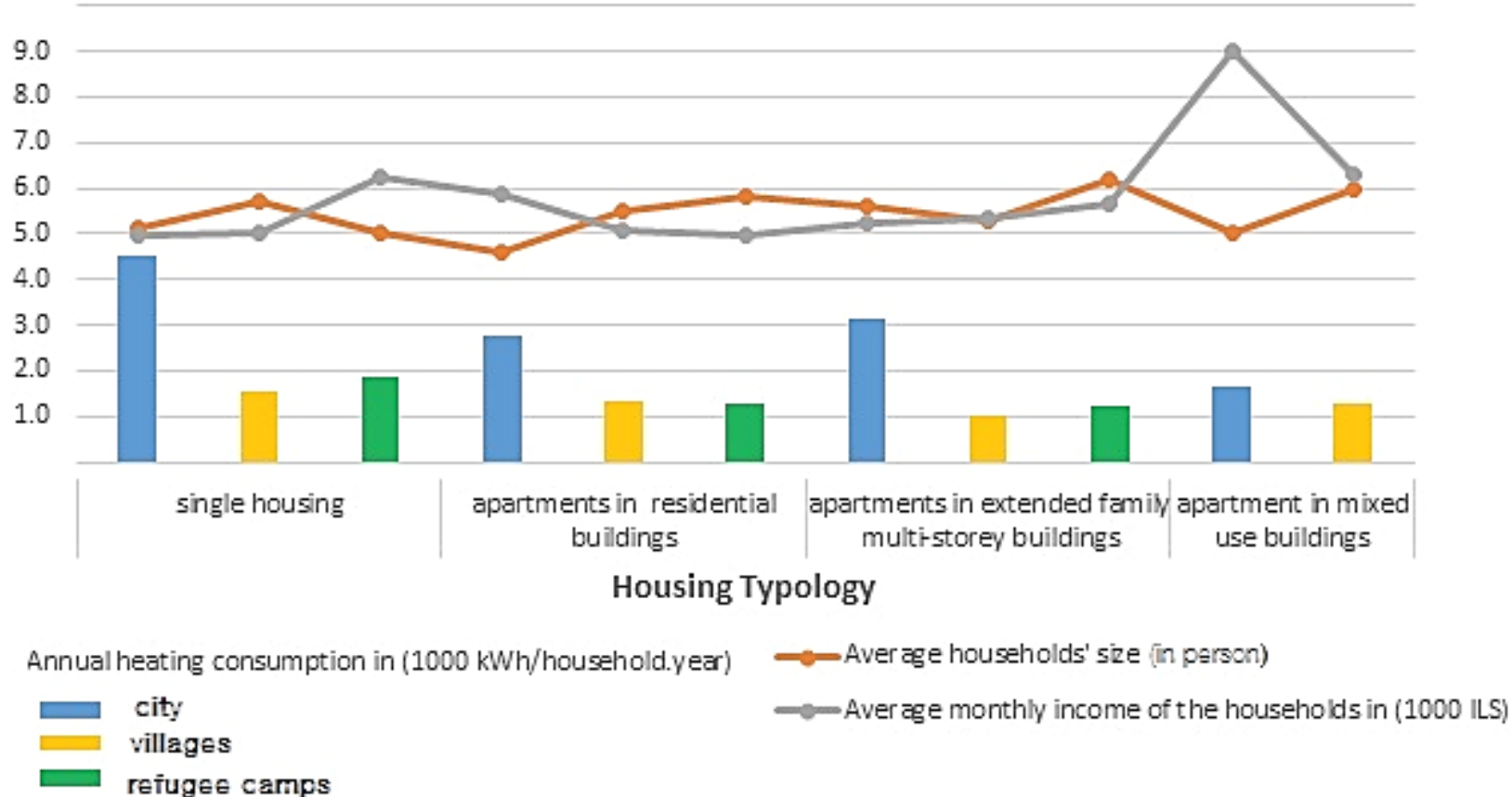

Fig 10: The Average Energy Consumption for Heating in the Housing Typologies in the Different Settlements vs. the Average Households' Size and the Average Monthly Households' Income

\subsection{Heating energy, total area and specific heating}

The house size and the number of rooms contribute towards the total energy consumption of a house (Morrison and Gladhart, 1976). Mileham and Brandt (1990) have found that the best predictor of money spent on energy is the size of a dwelling. However, in this study due to the other many socio-economic and political factors the energy consumed for heating shows no direct relationship with the total area as illustrated in Figure 12, which means that there is no direct relationship between the two variables. Other variables potentially have an impact on the heating energy consumption like the house layout, surface to volume ratio and openings to total area ratio which were not part of the survey. 


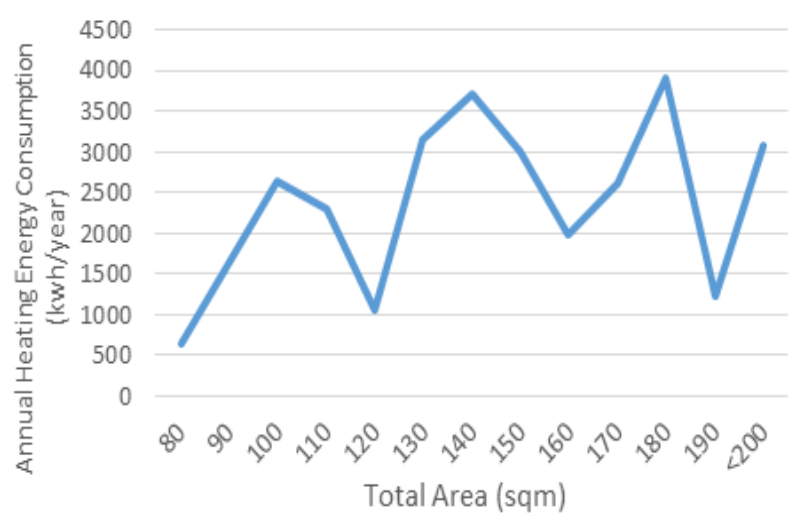

Fig 12: Heating energy vs. Total Area

The specific heating energy (energy/sqm) is the highest in the apartments in residential buildings

followed by the single housing and the apartments in extended family buildings respectively as shown in Figure 11. The average area of the apartments in residential buildings is less than the other types of housing as shown in Figure 6.

The specific heating energy (energy/sqm) is the highest in the apartments in residential buildings followed by the single housing and the apartments in extended family buildings respectively as shown in Figure 11. The average area of the apartments in residential buildings is less than the other types of housing as shown in Figure 6. Regarding the single housing, and despite that the average 1 area is the highest in this typology, single housing is more exposed to the external environment than the other housing typologies which means that the heating loss is higher and more heating is needed to maintain a certain level of warmth. The specific heating energy in the apartments in the extended family buildings and in mixed use buildings comes in third place and fourth place respectively which reflects the average area of these typologies in the survey.

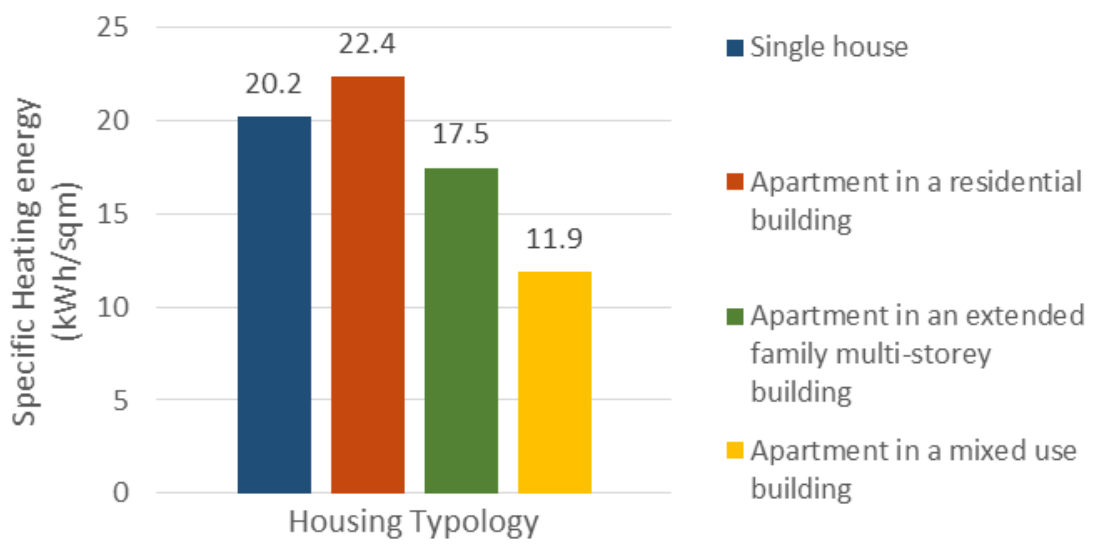

Fig 11: The Specific Heating Energy vs. Housing Typology 
Since no clear relationship between the house area and the heating energy found, the heated area is examined. The Palestinian households do not heat the entire house during winter. Basically, only the occupied areas are heated throughout the day as a result of economic limitations. In the survey, the households were asked to define the areas that were heated during different periods in a typical day during winter. The day was divided into five main periods, each is 4.8 hours long. The distribution of the heated spaces is illustrated in Figure 10. The chart shows that the majority of the households heated the living room during the afternoon and evening. The survey revealed that the majority of the households heated the guest room occasionally. Most of the households heated the bedroom during the evening before going to sleep. The results indicated that $33.5 \%$ and $43.2 \%$ of the households have never heated the kitchen or the bathrooms respectively. This is because cookers, ovens and other utilities in the kitchen produce heat which compensate for the heating demand. Figure 13 depicts the number of households that heated the different spaces during a typical winter day.

In order to calculate the nominal heated area, the area of the average room $(3.5 * 4 \mathrm{~m})$ was multiplied by 0.2 ( 4.8 divided by 24 hours) for each period during which the room was heated. For example, if the household heated the living room during the afternoon and evening and three bedrooms during 20 the evening, the nominal heated area in this case will be $(3.5 * 4 * 2 * 0.2)+(3.5 * 4 * 3 * 0.2)=14.0 \mathrm{~m}^{2}$ /day.

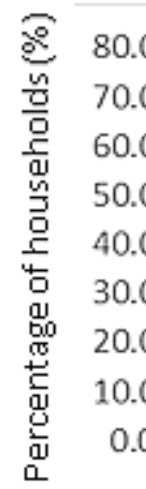

Figure 13: The Pattern of Heating the Different Spaces in the Houses during a Typical Day in Winter

Based on the analysis of 322 cases, the average nominal heated area in the houses was $12.1 \mathrm{~m}^{2} /$ day. This Figure represents $9.2 \%$ of the average housing area. The maximum nominal heated area did 
not exceed $11.1 \%$ of the total area of any of the 322 houses. The average nominal heated area was the highest in the city followed by the refugee camps and then the villages for the different housing typologies as shown in Figure 14. The nominal heated area varied between less than $4.0 \mathrm{~m}^{2} /$ day in the apartments in the residential buildings in the refugee camps to $14.0 \mathrm{~m}^{2} /$ day in the apartments in the extended family housing in the city. The variation could be due to a combination of parameters including comfort preferences, energy cost and occupancy rate that affects the duration of heating. The average calculated heated area of the single housing was very close in the city, the villages and the refugee camps. Similarly, not much variation was found between the calculated heated area in the city and the villages in the mixed-use housing. On the contrary, a discrepancy was noticed in the apartments in both extended family housing and the residential buildings in the three types of settlements. The previous discussion shows that the households spatial experience shrinks during winter due to the inability to heat all the areas in the house.

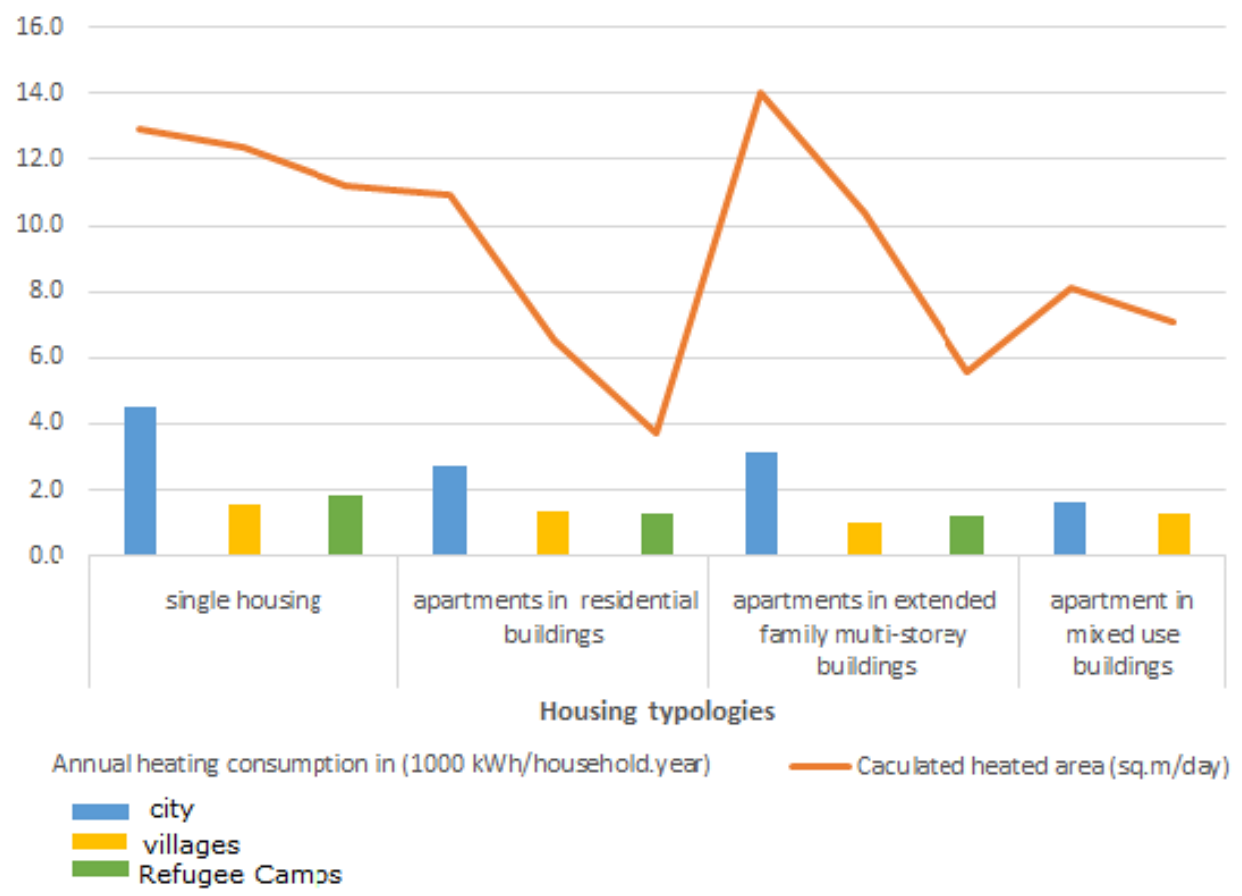

Figure 14: The Average Nominal Heated Area for the Different Housing Typologies in the Settlements in Hebron

\section{Developing a model for estimating the annual heating energy for Hebron}

For this research, a multi linear regression model is developed based completely on the empirical data collected in survey to predict the annual heating energy in the houses in Hebron by SPSS using Ridge Regression Analysis. Among the 17 factors that have been investigated in the survey, 14 factors were found to be significant in determining the energy consumed for heating as indicated in Table 10. The factors are considered to be significant if the Sig. (2-Tailed) value is less than 0.05. In addition to previously discussed factors, building material, occupancy period and the housing age were found important with Sig. (2-Tailed) value equals $0.000,0.022$ and 0.001 respectively. The 
data sets yielded the following Fitted Regression Equation (Model) for determining the annual heating energy consumption (Y):

$$
Y=-16042.2+\sum_{i=1}^{14} F(\text { Eq. } 7)
$$

Equation 4: Fitted Regression Equation (Model) for determining the annual heating energy consumption (Y)

Where $i$ is the $i$ th influencing factor and $F$ is the value of the factor as shown in Table 10. The households' size and the total area of the house are considered critical in determining the energy consumption in the housing sector (Badir, 2013; Mileham \& Brandt, 1990; Morrison \& Gladhart, 1976). In this study, the households' size and the total housing area had no significant impact on the energy used for heating. The Sig. (2-Tailed) value for the households' size was $0.238>0.05$, while for the total area it was $0.301>0.05$, indicating that these variables have no significant effect on the annual heating consumption. The explanation behind it, is that regardless of the households' size or the housing size, the family members spend their time together in a heated part of the house, basically one room. On the other hand, the nominal heated area has a significant effect on the heating energy consumed with a Sig. (2-Tailed) value of (0.00). Despite that their Sig. (2-Tailed) value were $>0.05$, using central heating and using the kerosene heaters were included in the factors since they had an effect on the $\mathrm{R}^{2}$ of the model.

\section{Model evaluation}

The $\mathrm{R}^{2}$ in this model is almost 0.606 , which means that the model can explain $60.6 \%$ of the energy used for heating. Figure 15 compares the fitted values of the regression analysis with the calculated values from the survey and shows the model performance. The study method used here may have certain limitations because it does not consider other important factors like orientation, adjacent buildings, building geometry, space layout, surface to volume ratio and openings to area ratio (Elseragy and Elnokaly; 2007). Obviously, there are several methods of estimating the heating energy consumption like simulation programs but such methods need detailed data which are not always available in the Palestinian context (Ren and Chen, 2015; Sami-Mecheri, Semmar and Hamid, 2015; Al Qadi, Sodagar and Elnokaly, 2017). The proposed model in this study is a simplified method that can be used as rule of thumb or a user-friendly method for estimating the energy consumed for heating in Hebron in the context where the detailed data is not available. 


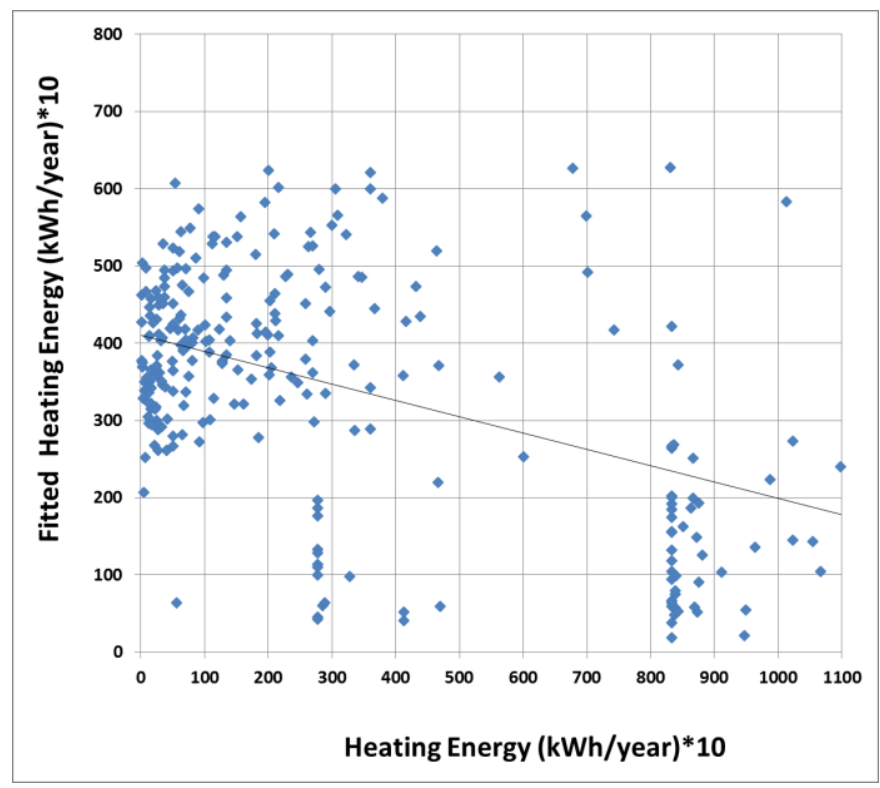

Figure 15: The Calculated vs. the Fitted Energy Used for Heating

\section{Conclusion}

In order to assist the shift towards more independent and sustainable energy technologies in Palestine the current energy consumption should be identified and optimized. This paper main contribution is a regression model that estimates the heating energy consumption in the residential sector in Hebron. With the absence of detailed data on heating energy consumption in Palestine, a model for estimating the annual energy consumption was developed using Ridge Regression Analysis with an $\mathrm{R}^{2}$ of 0.606 . The housing typology, housing age, building materials and wall insulation were important physical features in this model with Sig. (2-Tailed) equals 0.000 for all of them. The nominal heated area was an important determinant with a Sig. (2-Tailed) equals 0.000. The households' monthly income and occupancy period were found to have a significant impact on the amount of energy used for heating with Sig. (2-Tailed) equals 0.010 and 0.024 respectively. The type of settlement was found to have an impact on the annual heating energy consumption with Sig. (2-Tailed) equals 0.027 . The number of months during which the households heated their houses was influential with a Sig. (2-Tailed) equals 0.036. In addition, the type of heating systems were influential with Sig. (2-Tailed) varied between 0.000 and 0.134 . The model can be used as a simplified and user friendly tool to estimate the heating energy consumed by the Palestinian households in Hebron by professionals, policy makers and building industry. Future research is required to identify other influencing factors such as the building orientation, floor layout, fenestration design, and volume-to-surface ratio. 


\begin{tabular}{|c|c|c|c|c|c|c|c|c|c|}
\hline Factor $i$ & Description & Options & Value $(\mathbf{F})$ & $\begin{array}{c}\text { Sig. } \\
(2- \\
\text { Tailed) } \\
\text { value }\end{array}$ & Factor $i$ & Description & Options & Value (F) & $\begin{array}{l}\text { Sig. (2- } \\
\text { Tailed) } \\
\text { Value }\end{array}$ \\
\hline \multirow[t]{7}{*}{$F_{l}$} & \multirow{7}{*}{$\begin{array}{c}\text { The Housing } \\
\text { Typology }\end{array}$} & Single Housing & 279.351 & \multirow[t]{7}{*}{.000} & \multirow[t]{6}{*}{$F_{6}$} & \multirow{6}{*}{$\begin{array}{l}\text { The Family } \\
\text { Monthly } \\
\text { Income }\end{array}$} & Less Than 1500 Ils & 137.531 & \multirow[t]{6}{*}{.024} \\
\hline & & \multirow{2}{*}{$\begin{array}{l}\text { Apartment in a } \\
\text { Residential } \\
\text { Building }\end{array}$} & \multirow[t]{2}{*}{558.702} & & & & $1500-3000$ Ils & 275.062 & \\
\hline & & & & & & & $3000-5000 \mathrm{Ils}$ & \multirow{2}{*}{412.593} & \\
\hline & & \multirow{2}{*}{$\begin{array}{c}\text { Apartment in an } \\
\text { Extended Family } \\
\text { Building }\end{array}$} & \multirow[t]{2}{*}{838.053} & & & & $50007500 \mathrm{~J}$ & & \\
\hline & & & & & & & 5000-7500 Ils & 550.124 & \\
\hline & & \multirow{2}{*}{$\begin{array}{l}\text { Apartment in a } \\
\text { Mixed-Use } \\
\text { Building }\end{array}$} & \multirow[t]{2}{*}{1117.404} & & & & $7500-1000 \mathrm{Ils}$ & 687.655 & \\
\hline & & & & & \multirow{6}{*}{$F_{7}$} & \multirow{6}{*}{$\begin{array}{c}\text { The Housing } \\
\text { Age }\end{array}$} & Less Than 1 Year & 155.810 & \multirow{6}{*}{.001} \\
\hline \multirow[t]{4}{*}{$F_{2}$} & \multirow{4}{*}{$\begin{array}{c}\text { Type Of } \\
\text { Settlement }\end{array}$} & The City & 373.666 & \multirow{4}{*}{.011} & & & & & \\
\hline & & The & 717020 & & & & & 311.62 & \\
\hline & & & 141.332 & & & & 11-20 Years & 467.43 & \\
\hline & & $\begin{array}{l}\text { The } \\
\text { Refugee } \\
\text { Camps }\end{array}$ & 1120.998 & & & & 21-40 Years & 623.24 & \\
\hline \multirow[t]{4}{*}{$F_{3}$} & \multirow{4}{*}{$\begin{array}{c}\text { Walls } \\
\text { Insulation }\end{array}$} & Not Insulated & 329.968 & \multirow[t]{4}{*}{.000} & & & More Than 40 Years & 779.05 & \\
\hline & & Partially Insulated & 659.936 & & \multirow[t]{2}{*}{$F_{8}$} & \multirow{2}{*}{$\begin{array}{c}\text { Using Fire } \\
\text { Place }\end{array}$} & Yes & 3968.618 & \multirow[t]{2}{*}{.000} \\
\hline & & Fully & 989.904 & & & & No & 7937.236 & \\
\hline & & Not Sure & 1319.872 & & $F_{9}$ & Using Central & Yes & 977.411 & .101 \\
\hline \multirow[t]{3}{*}{$F_{4}$} & \multirow[t]{3}{*}{ Heated Area } & \multirow{3}{*}{$\begin{array}{c}\text { In (Sq.M/Day) as } \\
\text { Explained in } \\
\text { section 5.5. }\end{array}$} & \multirow{3}{*}{$\begin{array}{c}81.235^{*} \\
\text { Calculated } \\
\text { Heated Area }\end{array}$} & \multirow[t]{3}{*}{.000} & & & No & 1954.822 & \\
\hline & & & & & $F_{10}$ & Using Lpg & Yes & 1067.983 & .000 \\
\hline & & & & & & Heaters & No & & \\
\hline$F_{5}$ & The Main & $\begin{array}{l}\text { Brick, Concrete } \\
\text { and Stone }\end{array}$ & 281.799 & .000 & & & & 2073.546 & \\
\hline & Building & Concrete and & $-\cos \theta$ & & $F_{11}$ & Using & Ies & 1020.841 & .202 \\
\hline & Materials & Stone & 50.590 & & & Kerosene & No & 2135966 & \\
\hline & & $\begin{array}{c}\text { Bricks and } \\
\text { External Plaster }\end{array}$ & 845.397 & & & Heaters & & & \\
\hline & & Bricks And & & & $F_{12}$ & Using & Yes & 946.805 & .001 \\
\hline & & $\begin{array}{l}\text { (Stone on The } \\
\text { Main Façade and } \\
\text { Plaster on The } \\
\text { Remaining } \\
\text { Façades) }\end{array}$ & 1121.190 & & & $\begin{array}{l}\text { Electrical } \\
\text { Heating } \\
\text { Systems }\end{array}$ & No & 1893.61 & \\
\hline & & $\begin{array}{l}\text { Stone (Old } \\
\text { Buildings } \\
\text { System) }\end{array}$ & 1408.995 & & & & & & \\
\hline
\end{tabular}




\begin{tabular}{|c|c|c|c|c|}
\hline \multirow[t]{5}{*}{$F_{13}$} & \multirow{5}{*}{$\begin{array}{l}\text { Occupancy } \\
\text { period }\end{array}$} & Less Than & 181.179 & \multirow[t]{5}{*}{.022} \\
\hline & & 1-5 Years & 362.358 & \\
\hline & & $\begin{array}{l}11-20 \\
\text { Years }\end{array}$ & 543.537 & \\
\hline & & $\begin{array}{c}21-40 \\
\text { Years }\end{array}$ & 724.716 & \\
\hline & & $\begin{array}{l}\text { More } \\
\text { Than } 40 \\
\text { Years }\end{array}$ & 905.895 & \\
\hline
\end{tabular}

\begin{tabular}{|l|l|l|l|l|}
\hline$F_{14}$ & $\begin{array}{l}\text { Number of } \\
\text { Heated } \\
\text { Months }\end{array}$ & $\begin{array}{l}\text { One } \\
\text { month }\end{array}$ & 142.145 & .043 \\
\cline { 4 - 4 } & $\begin{array}{l}\text { Two } \\
\text { months }\end{array}$ & 284.29 \\
\cline { 4 - 4 } & $\begin{array}{l}\text { Three } \\
\text { months }\end{array}$ & 426.435 \\
\cline { 4 - 4 } & $\begin{array}{l}\text { Four } \\
\text { months }\end{array}$ & 568.58 \\
\cline { 3 - 4 } & $\begin{array}{l}\text { Five } \\
\text { months }\end{array}$ & 710.725 \\
\hline
\end{tabular}

\section{References}

- Abu-Madi, M. and Rayyan, M. (2013). Estimation of main greenhouse gases emission from household energy consumption in the West Bank, Palestine. Environmental Pollution, 179, pp.250-257.

- Aksoezen, M., Daniel, M., Hassler, U. and Kohler, N. (2015). Building age as an indicator for energy consumption. Energy and Buildings, 87, pp.74-86.

- Aly, Abdelrahman, Elnokaly, Amira and Mills, Glen (2017) Mind the gap: Methodology discussion of the extraction and analysis of pilot phase data to generate multi-configuration household behavioural profiles. Proceedings of 33rd PLEA International Conference Design to Thrive. Volume I.

- Al Qadi, S. and Alrjoub, M. (2011). The Economics of Solar Energy, Solar Energy in the Palestinian Schools. In: The 4th International Energy Conference. Ramallah: Engineers Association- Jerusalem Branch.

- Al Qadi, S., Sodagar, B. and Elnokaly, A. (2017). Predicting the Energy Performance of Buildings Under Present and Future Climate Scenarios- Lessons Learnt. In: FIRST INTERNATIONAL CONFERENCE ON CLIMATE CHANGE IPCCC 2017. Ramallah- Palestine: Engineers Association - Jerusalem Center.

- Aldridge, A. and Levine, K. (2001). Surveying the social world. Buckingham [etc.]: Open University Press.

- Alreck, P. and Settle, R. (2004). The survey research handbook. Boston (Mass.): McGraw-Hill//Irwin.

- Amiri, S., Mottahedi, M. and Asadi, S. (2015). Using multiple regression analysis to develop energy consumption indicators for commercial buildings in the U.S. Energy and Buildings, 109, pp.209-216.

- Anderson, D. (2003). Modern business statistics with microsoft excel. [Place of publication not identified]: CENGAGE LEARNING CUSTOM P.

- Andersson, B., Place, W., Kammerud, R. and Scofield, M. (1985). The impact of building orientation on residential heating and cooling. Energy and Buildings, 8(3), pp.205-224.

- Applied Research Institute - Jerusalem (ARIJ) (2009). Al Fawwar Refugee Camp Profile. [ebook] Available at: http://vprofile.arij.org/hebron/pdfs/Al\%20Fawwar\%20Camp_pr_en.pdf [Accessed 16 Aug. 2017].

- Asadi, S., Amiri, S. and Mottahedi, M. (2014). On the development of multi-linear regression analysis to assess energy consumption in the early stages of building design. Energy and Buildings, 85, pp.246-255.

- Baird, G. and Bieber, S. (2016). The Goldilocks Dilemma: Impacts of Multicollinearity -- A Comparison of Simple Linear Regression, Multiple Regression, and Ordered Variable Regression Models. Journal of Modern Applied Statistical Methods, 15(1), pp.332-357.

- Baker, T. (1999). Doing social research. Boston: McGraw-Hill College, pp.90-91.

- Barahmi, N. (2016). The Palestinian Directorate of Land and Property,2016.

- Bedir, M., Hasselaar, E. and Itard, L. (2013). Determinants of electricity consumption in Dutch dwellings. Energy and Buildings, 58, pp.194-207.

- Bethlehem, J. and Biffignandi, S. (2012). Wiley Handbook of Web Surveys. John Wiley \& Sons Inc.

- Biffignandi, S. and Bethlehem, J. (2012). Web Surveys: Methodological Problems and Research Perspectives. In: A. Di Ciaccio, M. Coli and J. Ibañez, ed., Advanced Statistical Methods for the Analysis of Large Data-Sets. Verlag Berlin Heidelberg: pringer, pp.363-373. 
- Bozdogan, H. (2004). Statistical data mining and knowledge discovery. Boca Raton, FL [etc.]: Chapman \& Hall/CRC, p.233.

- Brandon, G. and Lewis, A. (1999). REDUCING HOUSEHOLD ENERGY CONSUMPTION: A QUALITATIVE AND QUANTITATIVE FIELD STUDY. Journal of Environmental Psychology, 19(1), pp.75-85.

- Braun, M., Altan, H. and Beck, S. (2014). Using regression analysis to predict the future energy consumption of a supermarket in the UK. Applied Energy, 130, pp.305-313.

- Brøgger, M. and Wittchen, K. (2017). Estimating the energy-saving potential in national building stocks - A methodology review. Renewable and Sustainable Energy Reviews.

- Cai, J. and Jiang, Z. (2008). Changing of energy consumption patterns from rural households to urban households in China: An example from Shaanxi Province, China. Renewable and Sustainable Energy Reviews, 12(6), pp.16671680.

- Catalina, T., Iordache, V. and Caracaleanu, B. (2013). Multiple regression model for fast prediction of the heating energy demand. Energy and Buildings, 57, pp.302-312.

- Catalina, T., Virgone, J. and Blanco, E. (2008). Development and validation of regression models to predict monthly heating demand for residential buildings. Energy and Buildings, 40(10), pp.1825-1832.

- Creative Research systems. (2012). Sample size Calculator. [online] Available at: https://www.surveysystem.com/sscalc.htm [Accessed 21 Aug. 2017].

- Creswell, John W. (2003) Qualitative, Quantitative, and Mixed Methods Approaches, SAGE Publications

- Dong, B., Li, Z. and Mcfadden, G. (2015). An investigation on energy-related occupancy behavior for low-income residential buildings. Science and Technology for the Built Environment, 21(6), pp.892-901.

- Draper, N. and Smith, H. (2014). Applied Regression Analysis. Somerset: Wiley.

- Eckstein, Z. (2011). West Bank Economic Development and Industrialization.

- Electricité du Liban (2012). Lebanon Electricity Tariffs. [ebook] Available at: https://www.iec.co.il/EN/IR/Documents/tariff_1.4.12.pdf [Accessed 8 Feb. 2018].

- Elnokaly, Amira and Martin, Benjamin A. J. (2014) The impact of the UK governments spending review into the Feed in Tariff (FIT) on the installation of photovoltaic panels in the residential sector. World Journal of Science, Technology and Sustainable Development, 11 (2). pp.102 - 116. ISSN 2042-5945

- Elseragy, Ahmed and Elnokaly, Amira (2007) Assessment criteria for form environmental performance of building envelope in hot arid climates. In: Conference on Passive and Low Energy Architecture, 22-24 November 2007, National University of Singapore, Singapore.

- Elnokaly, Amira and Elseragy, Ahmed (2007a) What impedes the development of renewable energy technology in Egypt. In: MCEET 2007 Sustainable Energy: Technologies, Materials and Environmental Issues, Oct. 29-1 November, 2007, Cairo, Egypt.

- Elnokaly, Amira and Elseragy, Ahmed (2007b) An approach towards an energy efficient, green Mediterranean city in Alexandria, Egypt. In: SET 2007 - 6th International Conference on Sustainable Energy Technologies, 5-7 September 2007, Santiago, Chile.

- Europa (2015). EUROPA products catalog.

- Foucquier, A., Robert, S., Suard, F., Stéphan, L. and Jay, A. (2013). State of the art in building modelling and energy performances prediction: A review. Renewable and Sustainable Energy Reviews, 23, pp.272-288.

- Fowler, F. (2009). Survey Research Methods. SAGE.

- Fumo, N. and Rafe Biswas, M. (2015). Regression analysis for prediction of residential energy consumption. Renewable and Sustainable Energy Reviews, 47, pp.332-343.

- Growsave (2009). [online] Available at: http://www.growsave.co.uk/userFiles/050209_training_what_is_energy.pdf [Accessed 15 Aug. 2017].

- Guerra Santin, O., Itard, L. and Visscher, H. (2009). The effect of occupancy and building characteristics on energy use for space and water heating in Dutch residential stock. Energy and Buildings, 41(11), pp.1223-1232.

- Hu, S., Yan, D., Guo, S., Cui, Y. and Dong, B. (2017). A survey on energy consumption and energy usage behavior of households and residential building in urban China. Energy and Buildings, 148, pp.366-378.

- IBM, A. (2017). [online] Available at: http://www-01.ibm.com/software/analytics/spss/ [Accessed 15 Aug. 2017].

- Ibrik, I. (2009). Energy Profile and the Potential of Renewable Energy Sources in Palestine. Renewable Energy in the Middle East. NATO Science for Peace and Security Series C: Environmental Security. Dordrecht: Springer. 
- ICBS (2015). Average wages per employee job, by sector 2014. [online] Israeli Central Bureau of Statistics. Available at: http://www.cbs.gov.il/reader/shnaton/templ_shnaton_diag_e.html?num_tab=12_14\&CYear=2015 [Accessed 17 Aug. 2017].

- IEA (2014). International Energy Statistics. [online] Eia.gov. Available at: https://www.eia.gov/beta/international/data/browser/\#/?c=4100000002000060000000000000g00020000000000000 0001\&vs=INTL.44-1-AFRC-QBTU.A\&vo=0\&v=H\&start=1980\&end=2014 [Accessed 20 Aug. 2017].

- IEA, I. (n.d.). statistics. [online] Available at: http://www. iea.org/statistics/ [Accessed 4 Oct. 2017].

- InvestmentMine (2017). Historical Crude Oil Prices and Price Chart. [online] InfoMine. Available at: http://www.infomine.com/investment/metal-prices/crude-oil/all/ [Accessed 22 Aug. 2017].

- Ismail, M., Moghavvemi, M. and Mahlia, T. (2013). Energy trends in Palestinian territories of West Bank and Gaza Strip: Possibilities for reducing the reliance on external energy sources. Renewable and Sustainable Energy Reviews, 28, pp.117-129.

- Israeli Ministry of National Infrastructures (2018), Archive.energy.gov.il. Available at: http://archive.energy.gov.il/English/Subjects/Subject/Pages/GxmsMniPricesAndTaxes.aspx [Accessed 6 Feb. 2018].

- Jordan Ministry of Energy and Mineral Resources (2017). Retail Prices of Petroleum Products.

- Jridi, O. and Nouri, F. (2015). Survey of socio-economic and contextual factors of households' energy consumption. Data in Brief, 5, pp.327-332.

- Juaidi, A., Montoya, F., Ibrik, I. and Manzano-Agugliaro, F. (2016). An overview of renewable energy potential in Palestine. Renewable and Sustainable Energy Reviews, 65, pp.943-960.

- Kavgic, M., Mavrogianni, A., Mumovic, D., Summerfield, A., Stevanovic, Z. and Djurovic-Petrovic, M. (2010). A review of bottom-up building stock models for energy consumption in the residential sector. Building and Environment, 45(7), pp.1683-1697.

- Kneifel, J. and Webb, D. (2016). Predicting energy performance of a net-zero energy building: A statistical approach. Applied Energy, 178, pp.468-483.

- Kolokotroni, M. and Giridharan, R.(2008). Urban heat island intensity in London: An investigation of the impact of physical characteristics on changes in outdoor air temperature during summer. Solar Energy, 82(11), pp.986-998.

- Kumar, R., Aggarwal, R. and Sharma, J. (2013). Energy analysis of a building using artificial neural network: A review. Energy and Buildings, 65, pp.352-358.

- Lannon, S., Charles, I., Eames, H. and Hunt, M. (2016). Energy modelling of regions using stakeholder generated visions as scenarios. In: International Conference 'Smart Energy Regions. [online] Cardiff, Wales, pp.84-96. Available at: http://orca.cf.ac.uk/88952/7/PP-15\%20-\%20Lannon_final.pdf [Accessed 28 Sep. 2017].

- Lazzeronia, P., Oliveroa, S., Stiranoa, F., Miconob, C., Montaldob, P., Zanzotterab, G., Cal'1 c, F. and Repettoc, M. (2017). Energy efficiency measures for buildings in Hebron city and their expected impacts in the distribution grid. In: 9th International Conference on Sustainability in Energy and Buildings. [online] Energy Procedia. Available at: https://www.researchgate.net/publication/318378492_Energy_efficiency_measures_for_buildings_in_Hebron_city _and_their_expected_impacts_in_the_distribution_grid [Accessed 9 Oct. 2017].

- Lebanese Ministry of Energy and Water. (2018) Available at: http://www.energyandwater.gov.lb/ar

- Lü, X., Lu, T., Kibert, C. and Viljanen, M. (2015). Modeling and forecasting energy consumption for heterogeneous buildings using a physical-statistical approach. Applied Energy, 144, pp.261-275.

- Matsumoto, S. (2016). How do household characteristics affect appliance usage? Application of conditional demand analysis to Japanese household data. Energy Policy, 94, pp.214-223.

- McPeake, J., Bateson, M. and O'Neill, A. (2014). Electronic surveys: how to maximise success. Nurse Researcher, 21(3), pp.24-26.

- Media (2015). Midea products catalog. Media.

- Mileham, C. and Brandt, J. (1990). Influence of Income on Energy Beliefs and Behaviors of Urban Elderly. Journal of Housing For the Elderly, 6(1-2), pp.107-124.

- Mocanu, E., Nguyen, P., Gibescu, M. and Kling, W. (2016). Deep learning for estimating building energy consumption. Sustainable Energy, Grids and Networks, 6, pp.91-99.

- Montgomry, D., Peck, E. and Vining, G. (2012). Introduction to Linear Regression Analysis. 5th ed. John Wiley \& Sons, 2015, pp.1-4.

- Morrison, B. and Gladhart, P. (1976). Energy and Families: The Crisis and the Response. Journal of home economics, 68(1). 
- Mutani, G., Delmastro, C., Gargiulo, M. and Corgnati, S. (2016). Characterization of Building Thermal Energy Consumption at the Urban Scale. Energy Procedia, 101, pp.384-391.

- Narasimha Rao, M. and Reddy, B. (2007). Variations in energy use by Indian households: An analysis of micro level data. Energy, 32(2), pp.143-153.

- Nejat, P., Jomehzadeh, F., Taheri, M., Gohari, M. and Abd. Majid, M. (2015). A global review of energy consumption, $\mathrm{CO} 2$ emissions and policy in the residential sector (with an overview of the top ten $\mathrm{CO} 2$ emitting countries). Renewable and Sustainable Energy Reviews, 43, pp.843-862.

- NEPC (2013). Nationl Electric Power Company - NEPCO HomePage. [online] Nepco.com.jo. Available at: http://www.nepco.com.jo/en/electricity_tariff_en.aspx [Accessed 15 Aug. 2017].

- NEPC (2017). Electricity Tariff in Jordan. National Electric Power Company.

- Oh, S., Ng, K., Thu, K., Chun, W. and Chua, K. (2016). Forecasting long-term electricity demand for cooling of Singapore's buildings incorporating an innovative air-conditioning technology. Energy and Buildings, 127, pp.183193.

- Ouda, M. (2010). Analysis and prediction of household energy consumption in west bank and Gaza strip. The Islamic University Journal, 18(1), pp.77-98.

- Palestinian Electricity Regulatory Council (2017). Electricity Prices for the housing sector.

- Palestinian National Authority Ministry of Finance (2017). المالية وزارة - الرئيسية. [online] Pmof.ps. Available at: http://www.pmof.ps/en/ [Accessed 16 Aug. 2017].

- Park, J., Lee, S., Kim, K., Kwon, K. and Jeong, J. (2016). Estimating thermal performance and energy saving potential of residential buildings using utility bills. Energy and Buildings, 110, pp.23-30.

- PASSIA (2001). 100 Years of Palestinian History. Jerusalem: Passia Publication.

- PCBS (2000). Energy Consumption in Palestine 1998. [online] Ramallah- Palestine: PCBS. Available at: http://www.pcbs.gov.ps/Downloads/book668.pdf [Accessed 16 Aug. 2017].

- PCBS (2004). Palestinian Central Bureau of Statistics Release Results of Household Energy Survey (July 2004). [online] Available at: http://www.pcbs.gov.ps/Portals/_pcbs/PressRelease/engjuly04_e.pdf [Accessed 16 Aug. 2017].

- PCBS (2006). Release Results of Household Energy Survey (January 2005). [online] Available at: http://www.pcbs.gov.ps/Portals/_pcbs/PressRelease/houseenergy_jul06e.pdf [Accessed 21 Aug. 2017].

- PCBS (2010). الإحصائي الخليل محافظة [Hebron Governorate statistics Book. 2nd ed.] Ramallah: Palestinian Central Bureau of Statistics.

- PCBS (2011). Household Energy Survey. [online] Palestinain Central Bureau of Statistics, p.p3. Available at: http://www.pcbs.gov.ps/Portals/_Rainbow/Documents/Household\%20Energy\%20Survey\%20Tables\%20(July\%20 2011).pdf [Accessed 17 Aug. 2017].

- PCBS (2014). Access and Use of ICT by Households and Individuals by Year. Palestinian Central Bureau of Statistics.

- PCBS (2015). Energy Survey December/2015. [online] Ramallah, Palestine: PCBS. Available at: http://www.pcbs.gov.ps/Downloads/book2134.pdf [Accessed 20 Aug. 2017].

- PCBS (2016a). Localities in Hebron Governorate by Type of Locality and Population Estimates, 2007-2016. Palestinian Central Bureau of Statistics.

- PCBS $\left(2016_{\mathrm{b}}\right)$. Performance of Palestinian Economy 2016. [online] Ramallah, Palestine: Palestinian Central Bureau of Statistics, p.p18. Available at: http://www.pcbs.gov.ps/Downloads/book2268.pdf [Accessed 17 Aug. 2017].

- PCBS $\left(2016_{\mathrm{c}}\right)$. Mean of Air Temperatures $\left({ }^{\circ} \mathrm{C}\right)$ in Palestine by Station Location and Year, 2009-2016. [online] Palestinian Central Bureau of Statitics. Available at: http://www.pcbs.gov.ps/Portals/_Rainbow/Documents/Metr1te2016.htm [Accessed 16 Aug. 2017].

- Pressman, J. (2006). The Second Intifada: Background and Causes of the Israeli-Palestinian Conflict. [online] Journals.lib.unb.ca. Available at: https://journals.lib.unb.ca/index.php/jcs/article/view/220/378 [Accessed 21 Aug. 2017].

- Pulido-Arcas, J., Pérez-Fargallo, A. and Rubio-Bellido, C. (2016). Multivariable regression analysis to assess energy consumption and $\mathrm{CO} 2$ emissions in the early stages of offices design in Chile. Energy and Buildings, 133, pp.738-753.

- Ren, Z. and Chen, D. (2015). Simulation of Air Infiltration of Australian Housing and its Impact on Energy Consumption. Energy Procedia, 78, pp.2717-2723. 
- Roscoe, J. (1975). Fundamental research statistics for the behavioral sciences. New York: Holt, Rinehart and Winston.

- Salvati, A., Coch Roura, H. and Cecere, C. (2017). Assessing the urban heat island and its energy impact on residential buildings in Mediterranean climate: Barcelona case study. Energy and Buildings, 146, pp.38-54.

- Sami-Mecheri, S., Semmar, D. and Hamid, A. (2015). Determination of the Energetic Needs of Low Energy Housing and Integration of a Solar Water Heating Installation Located in Algeria. Energy Procedia, 74, pp.854-863.

- Santamouris, M. (2016). Innovating to zero the building sector in Europe: Minimising the energy consumption, eradication of the energy poverty and mitigating the local climate change. Solar Energy, 128, pp.61-94.

- Santamouris, M., Paravantis, J., Founda, D., Kolokotsa, D., Michalakakou, P., Papadopoulos, A., Kontoulis, N., Tzavali, A., Stigka, E., Ioannidis, Z., Mehilli, A., Matthiessen, A. and Servou, E. (2013). Financial crisis and energy consumption: A household survey in Greece. Energy and Buildings, 65, pp.477-487.

- Sardianou, E. (2008). Estimating space heating determinants: An analysis of Greek households. Energy and Buildings, 40(6), pp.1084-1093.

- Schwarz, N., Schlink, U., Franck, U. and Großmann, K. (2012). Relationship of land surface and air temperatures and its implications for quantifying urban heat island indicators-An application for the city of Leipzig (Germany). Ecological Indicators, 18, pp.693-704.

- Sesan, T. (2012). Navigating the limitations of energy poverty: Lessons from the promotion of improved cooking technologies in Kenya. Energy Policy, 47, pp.202-210.

- Shahin, H. (2004). Management of Olive Mills Wastes in the Palestinian Territories. In: Recent trends in the management of environmentally polluting wastes. [online] Sharm Shiekh- Egypt. Available at: https://staffold.najah.edu/sites/default/files/Management_of_Olive_Mills_Wastes_in_the_Palestinian_Territories.pdf [Accessed 16 Aug. 2017].

- Sodagar, B. and Starkey, D. (2016). The monitored performance of four social houses certified to the Code for Sustainable Homes Level 5. Energy and Buildings, 110, pp.245-256.

- Swan, L. and Ugursal, V. (2009). Modeling of end-use energy consumption in the residential sector: A review of modeling techniques. Renewable and Sustainable Energy Reviews, 13(8), pp.1819-1835.

- The Israel Electric Corporation LTD. (2012). Electricity tariff. Available at: https://www.iec.co.il/EN/IR/Documents/tariff_1.4.12.pdf [Accessed 8 Feb. 2018].

- Tiwari, P. (2000). Architectural, Demographic, and Economic Causes of Electricity Consumption in Bombay. Journal of Policy Modeling, 22(1), pp.81-98.

- Tso, G. and Guan, J. (2014). A multilevel regression approach to understand effects of environment indicators and household features on residential energy consumption. Energy, 66, pp.722-731.

- Universal (2015). Universal products catalog. Universal.

- Upadhyay, A., Ding, L., Yee, K. and Prasad, D. (2017). Post-occupancy Energy Consumption of BASIX Affected Dwellings in the Sydney Metropolitan Area. Procedia Engineering, 180, pp.331-342.

- Viggers, H., Keall, M., Wickens, K. and Howden-Chapman, P. (2017). Increased house size can cancel out the effect of improved insulation on overall heating energy requirements. Energy Policy, 107, pp.248-257.

- Wall, R. and Crosbie, T. (2009). Potential for reducing electricity demand for lighting in households: An exploratory socio-technical study. Energy Policy, 37(3), pp.1021-1031.

- Wan, A. (2002). On generalized ridge regression estimators under collinearity and balanced loss. Applied Mathematics and Computation, 129(2-3), pp.455-467.

- Wang, R. and Jiang, Z. (2017). Energy consumption in China's rural areas: A study based on the village energy survey. Journal of Cleaner Production, [online] 143(1 Feb 2017). Available at: http://www.sciencedirect.com/science/article/pii/S0959652616321448.

- Wei, S., Jones, R. and de Wilde, P. (2014). Driving factors for occupant-controlled space heating in residential buildings. Energy and Buildings, 70, pp.36-44.

- Yan, X. and Su, X. (2009). Linear regression analysis. Hackensack, N.J.: World Scientific.

- Yaseen, B. (2009). Renewable Energy Applications in Palestine. In: DISASTRES Conference. [online] Available at: https://scholar.najah.edu/sites/default/files/conference-paper/renewable-energy-applications-palestine.pdf [Accessed 15 Aug. 2017].

- Zheng, X., Wei, C., Qin, P., Guo, J., Yu, Y., Song, F. and Chen, Z. (2014). Characteristics of residential energy consumption in China: Findings from a household survey. Energy Policy, 75, pp.126-135. 